Article

\title{
The Inflammasome Adaptor Protein ASC in Mild Cognitive Impairment and Alzheimer's Disease
}

\author{
Xavier O. Scott ${ }^{1}$, Marisa E. Stephens ${ }^{2}$, Marie C. Desir ${ }^{2}{ }^{-}$, W. Dalton Dietrich ${ }^{2,3,4}$, \\ Robert W. Keane ${ }^{1,2,4}$ and Juan Pablo de Rivero Vaccari $2,3,4, *$ D \\ 1 Department of Physiology and Biophysics, University of Miami Miller School of Medicine, \\ Miami, FL 33136, USA; x.scott@miami.edu (X.O.S.); rkeane@miami.edu (R.W.K.) \\ 2 Department of Neurological Surgery and The Miami Project to Cure Paralysis, University of Miami Miller \\ School of Medicine, Miami, FL 33136, USA; mes129@miami.edu (M.E.S.); \\ m.desir1@med.miami.edu (M.C.D.); DDietrich@med.miami.edu (W.D.D.) \\ 3 Center for Cognitive Neuroscience and Aging, University of Miami Miller School of Medicine, \\ Miami, FL 33136, USA \\ 4 InflamaCORE, LLC. Miami, FL 33156, USA \\ * Correspondence: jderivero@med.miami.edu; Tel.: +1-305-243-1252
}

Received: 11 June 2020; Accepted: 29 June 2020; Published: 30 June 2020

check for updates

\begin{abstract}
Mild cognitive impairment (MCI) is characterized by memory loss in the absence of dementia and is considered the translational stage between normal aging and early Alzheimer's disease (AD). Patients with MCI have a greater risk of advancing to AD. Thus, identifying early markers of MCI has the potential to increase the therapeutic window to treat and manage the disease. Protein levels of the inflammasome signaling proteins apoptosis-associated speck-like protein containing a caspase recruitment domain (ASC) and interleukin (IL)-18 were analyzed in the serum of patients with MCI, AD and healthy age-matched donors as possible biomarkers, as well as levels of soluble amyloid precursor proteins $\alpha / \beta(\mathrm{sAPP} \alpha / \beta)$ and neurofilament light (NfL). Cut-off points and positive and negative predictive values, as well as receiver operator characteristic (ROC) curves, likelihood ratios and accuracy were determined for these proteins. Although the levels of ASC were higher in MCI and AD than in age-matched controls, protein levels of ASC were higher in MCI than in AD cases. For control vs. MCI, the area under the curve (AUC) for ASC was 0.974, with a cut-off point of $264.9 \mathrm{pg} / \mathrm{mL}$. These data were comparable to the AUC for sAPP $\alpha$ and $\beta$ of 0.9687 and 0.9068 , respectively, as well as 0.7734 for NfL. Moreover, similar results were obtained for control vs. AD and MCI vs. AD. These results indicate that ASC is a promising biomarker of MCI and AD.
\end{abstract}

Keywords: mild cognitive impairment; Alzheimer's disease; serum biomarkers; inflammaging; inflammasome; ASC; neurodegeneration

\section{Introduction}

Alzheimer's disease (AD) is a neurodegenerative disorder characterized by cognitive and memory decline that worsens over time [1]. The transitional stage between normal aging and early AD is referred to as mild cognitive impairment (MCI) [2]. MCI is characterized by memory impairment in the absence of dementia [3]. Patients with MCI are at greater risk of progressing to AD [4,5]. As a result, it is imperative to identify early markers of MCI that may be used in the monitoring and diagnosis of these patients prior to the development of AD. It is possible that early identification of AD, potentially at the MCI stage, has the benefit to increase therapeutic efficacy when compared to more advanced AD cases.

Cerebrospinal fluid (CSF) amyloid- $\beta\left(\mathrm{A} \beta_{(1-42)}\right)$ is a promising biomarker for MCI and AD with a specificity and sensitivity above $80 \%$ [6]. A $\beta_{(1-42)}$ is present at moderately low levels in cases of Lewy 
body dementia [7] and decreased in vascular dementia [8]. Similarly, mean Total (T)-tau levels are three times higher in the CSF of AD patients than in controls, with a sensitivity of $82 \%$ and a specificity of $88 \%$ [9]. Moreover, patients with MCI that develop AD present with high levels of T-tau, with $90 \%$ sensitivity and $100 \%$ specificity [10]. In addition, soluble amyloid precursor proteins (sAPP) $\alpha$ and $\beta$ have been shown to be potentially effective biomarkers that may be used in the care of patients with $\mathrm{MCI}$ and $\mathrm{AD}[11]$.

Neurofilament light chain (NfL) is a cytoskeletal protein and biomarker of axonal damage. NfL levels in the blood (serum and plasma) are correlated with CSF NfL levels [12]. Additionally, plasma NfL levels were shown to be positively correlated with raised cortical microglial activity in brain regions commonly associated with MCI and AD [13]. Moreover, higher plasma and CSF NfL levels correlate with hypometabolism in brain regions consistent with AD [14]. Thus, it appears that NfL levels, combined with additional neuroinflammatory proteins levels, would increase the accuracy of biomarkers to monitor and treat cognitive decline.

Neuroinflammatory responses have been shown to contribute to the underlying pathology of neurodegenerative diseases like MCI, AD and Parkinson's disease [15]. An inflammatory response as a result of aging is referred to as inflammaging. It has been previously shown that the inflammasome contributes to the naturally occurring process of inflammaging, which likely represents the initial stages of cognitive impairment and neurodegeneration [16-19]. The inflammasome is a multiprotein complex responsible for the production of interleukin (IL)-1 $\beta$ and IL-18 upon activation of inflammatory caspase-1 [20]. Inflammasome proteins are secreted and play a role in the spread of the inflammatory response. [21] Therefore, secreted inflammasome proteins are promising biomarkers of inflammation. Accordingly, inflammasome proteins have been shown to serve as biomarkers of brain injury [22], stroke [23], multiple sclerosis [24] and depression [25]. Moreover, the inflammasome adaptor protein apoptosis-associated speck-like protein containing a caspase recruitment domain (ASC) has been shown to have prionoid properties, and after secretion, ASC contributes to the spread of inflammation [21]. In addition, ASC forms an aggregate complex with $\mathrm{A} \beta$, which promotes inflammation and pyroptosis in the microglia of mice. $[26,27]$ Thus, the inflammasome is a key contributor to the inflammatory response in $\mathrm{AD}$ pathology.

Here, we extend our previous studies to investigate the potential of inflammasome proteins as biomarkers of $\mathrm{MCI}$ and $\mathrm{AD}$. We calculated cut-off points, receiver operator characteristic (ROC) curves with associated sensitivity and specificity calculations for the inflammasome proteins ASC and IL-18. In addition, we performed similar analyses for soluble APP $\alpha$ and $\beta(\operatorname{sPP} \alpha / \beta)$ and serum NfL to evaluate whether inflammasome proteins serve as more reliable markers for $\mathrm{MCI}$ and $\mathrm{AD}$ [11].

\section{Results}

\subsection{ASC and IL-18 Are Elevated in the Serum of Patients with MCI and AD}

To investigate if inflammasome signaling proteins could serve as biomarkers of $\mathrm{MCI}$ and $\mathrm{AD}$, we analyzed serum samples from patients with $\mathrm{MCI}, \mathrm{AD}$ and aged-matched donors for the expression of ASC (Figure 1A) and IL-18 (Figure 1B). Protein levels of ASC and IL-18 were significantly higher in the $\mathrm{MCI}$ than in the control group. In addition, serum levels of ASC were found to be significantly higher in $\mathrm{MCI}$ than $\mathrm{AD}$ patients (Figure 1A). However, there was no statistically significant difference between the serum levels of IL-18 in the MCI vs. AD groups (Figure 1B), suggesting a biomarker role for ASC in the pathology of MCI and AD and IL-18 in MCI. 
A

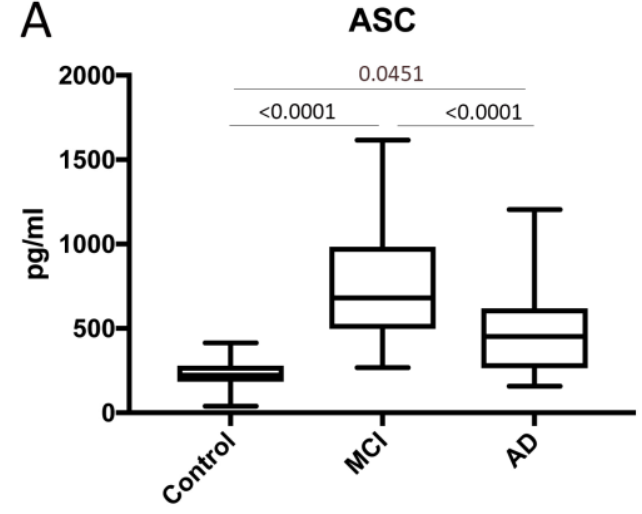

B

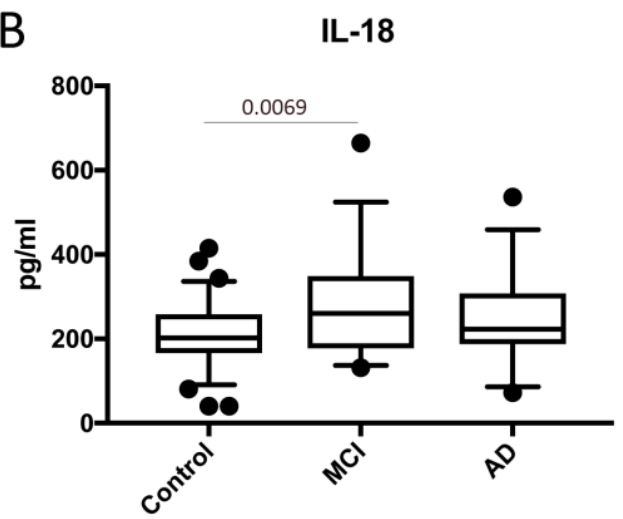

Figure 1. Apoptosis-associated speck-like protein containing a caspase recruitment domain (ASC) and interleukin (IL)-18 are elevated in the serum of patients with mild cognitive impairment (MCI) and Alzheimer's disease (AD). Protein levels in pg/mL for ASC (A) and (B) IL-18 in the serum from patients with MCI, AD and controls. ASC: $n=66$ control, $32 \mathrm{MCI}$ and $31 \mathrm{AD}$. IL-18: $n=69$ control, $31 \mathrm{MCI}$ and $32 \mathrm{AD}$. Box and whiskers are shown for the 5th and 95th percentiles.

\subsection{ASC Is a Promising Serum Biomarker of MCI and AD}

To determine if inflammasome signaling proteins may be used as biomarkers of $\mathrm{MCI}$ and $\mathrm{AD}$, we determined the area under the curve (AUC) for the control vs. $\mathrm{MCI}, \mathrm{MCI}$ vs. AD and control vs. AD (Tables 1 and 2) for ASC and IL-18. For the control vs. MCI, of the inflammasome signaling proteins analyzed, ASC presented the highest AUC of $0.974(p<0.0001)$, and IL-18 had an AUC of $0.6896(p=0.0025)$ (Table 1 ); the cut-off point for ASC was $264.9 \mathrm{pg} / \mathrm{mL}$ with $100 \%$ sensitivity and $74 \%$ specificity, whereas IL-18 had a cut-off point of $213.9 \mathrm{pg} / \mathrm{mL}$ with $74 \%$ sensitivity and $58 \%$ specificity (Table 2). For the control vs. AD, the AUC for ASC was $0.8328(p<0.0001)$ (Table 1), with a cut-off point of $258.7 \mathrm{pg} / \mathrm{mL}$ with $81 \%$ sensitivity and $71 \%$ specificity (Table 2). Finally, for MCI vs. AD, the AUC for ASC was $0.7157(p=0.0033$ ) (Table 1$)$, with a cut-off point of $<560 \mathrm{pg} / \mathrm{mL}$ and a $71 \%$ sensitivity and a $63 \%$ specificity (Table 2 ).

Table 1. Area under the curve. MCI: mild cognitive impairment, AD: Alzheimer's disease, IL: interleukin, sAPP: soluble amyloid precursor proteins and NfL: neurofilament light.

\begin{tabular}{ccccc}
\hline Biomarker & Area & Std. Error & 95\% C.I. & $p$-Value \\
\hline \multicolumn{5}{c}{ Control vs. MCI } \\
\hline ASC & 0.974 & 0.01301 & 0.9485 to 0.9995 & $<0.0001$ \\
\hline IL-18 & 0.6896 & 0.06086 & 0.5703 to 0.8089 & 0.0025 \\
\hline sAPP $\alpha$ & 0.9687 & 0.0216 & 0.9263 to 1.011 & $<0.0001$ \\
\hline sAPP $\beta$ & 0.9068 & 0.03784 & 0.8327 to 0.981 & $<0.0001$ \\
\hline NfL & 0.7734 & 0.05821 & 0.6594 to 0.8875 & 0.0002 \\
\hline ASC & 0.8328 & 0.05053 & 0.7338 to 0.9319 & $<0.0001$ \\
\hline IL-18 & 0.6105 & 0.06124 & 0.4905 to 0.7305 & 0.0749 \\
\hline sAPP $\alpha$ & 0.9563 & 0.02490 & 0.9074 to 1.005 & $<0.0001$ \\
\hline sAPP $\beta$ & 0.9185 & 0.03592 & 0.8481 to 0.9889 & $<0.0001$ \\
\hline NfL & 0.7165 & 0.06817 & 0.5829 to 0.8501 & 0.0040 \\
\hline
\end{tabular}


Table 1. Cont.

\begin{tabular}{ccccc}
\hline Biomarker & Area & Std. Error & 95\% C.I. & $p$-Value \\
\hline \multicolumn{5}{c}{ MCI vs. AD } \\
\hline ASC & 0.7157 & 0.06472 & 0.5889 to 0.8426 & 0.0033 \\
\hline IL-18 & 0.5847 & 0.07332 & 0.441 to 0.7284 & 0.2482 \\
\hline sAPP $\alpha$ & 0.6351 & 0.07146 & 0.4950 to 0.7752 & 0.0654 \\
\hline sAPP $\beta$ & 0.5247 & 0.07514 & 0.3774 to 0.6720 & 0.7401 \\
\hline NfL & 0.5569 & 0.07502 & 0.4099 to 0.7040 & 0.4498 \\
\hline
\end{tabular}

Table 2. Sensitivity and specificity. PPV: positive predictive values and NPV: negative predictive values.

\begin{tabular}{|c|c|c|c|c|c|c|c|}
\hline Biomarker & $\begin{array}{l}\text { Cut-Off Point } \\
(\mathrm{pg} / \mathrm{mL})\end{array}$ & $\begin{array}{l}\text { Sensitivity } \\
(\%)\end{array}$ & $\begin{array}{l}\text { Specificity } \\
(\%)\end{array}$ & $\begin{array}{l}\text { PPV } \\
(\%)\end{array}$ & $\begin{array}{l}\text { NPV } \\
(\%)\end{array}$ & $\begin{array}{l}\text { Likelihood } \\
\text { Ratio }\end{array}$ & $\begin{array}{c}\text { Accuracy } \\
(\%)\end{array}$ \\
\hline \multicolumn{8}{|c|}{ Control vs. MCI } \\
\hline ASC & $>264.9$ & 100 & 74 & 65 & 100 & 3.882 & 83 \\
\hline IL-18 & $>213.9$ & 74 & 58 & 44 & 83 & 1.765 & 63 \\
\hline SAPP $\alpha$ & $>1.39(\mathrm{ng} / \mathrm{mL})$ & 97 & 74 & 81 & 95 & 3.763 & 86 \\
\hline SAPP $\beta$ & $>0.2639(\mathrm{ng} / \mathrm{mL})$ & 90 & 78 & 78 & 90 & 4.065 & 84 \\
\hline NfL & $>24.15$ & 72 & 75 & 71 & 75 & 2.875 & 74 \\
\hline \multicolumn{8}{|c|}{ Control vs. AD } \\
\hline ASC & $>258.7$ & 81 & 71 & 57 & 89 & 2.801 & 74 \\
\hline IL-18 & $>196.5$ & 72 & 42 & 37 & 76 & 1.24 & 51 \\
\hline SAPP $\alpha$ & $>2.573(\mathrm{ng} / \mathrm{mL})$ & 91 & 91 & 92 & 90 & 10.57 & 91 \\
\hline sAPP $\beta$ & $>0.2906(\mathrm{ng} / \mathrm{mL})$ & 83 & 81 & 80 & 85 & 4.5 & 82 \\
\hline NfL & $>21.48$ & 64 & 56 & 56 & 64 & 1.469 & 60 \\
\hline \multicolumn{8}{|c|}{ MCI vs. AD } \\
\hline ASC & $<560.0$ & 71 & 63 & 65 & 69 & 1.892 & 67 \\
\hline IL-18 & $>290.3$ & 72 & 48 & 59 & 63 & 1.393 & 60 \\
\hline sAPP $\alpha$ & $<8.846(\mathrm{ng} / \mathrm{mL})$ & 72 & 55 & 64 & 63 & 1.592 & 64 \\
\hline SAPP $\beta$ & $>0.6364(\mathrm{ng} / \mathrm{mL})$ & 60 & 45 & 49 & 56 & 1.094 & 52 \\
\hline NfL & $<33.92$ & 71 & 44 & 53 & 64 & 1.27 & 57 \\
\hline
\end{tabular}

\section{3. $M C I, A D$ and $S A P P \alpha / S A P P \beta$}

APP protein levels have been shown to be consistent with the pathology of AD and MCI; thus, it appears that APP is also a promising biomarker for these conditions [11]. Thus, to compare our findings with other more established biomarkers of $\mathrm{MCI}$ and $\mathrm{AD}$, we compared the serum protein levels of ASC and SAPP $\alpha / \mathrm{sAPP} \beta$ for the ability to distinguish between MCI, AD and the controls. In our study, the protein levels of sAPP $\alpha$ (Figure 2A) and sAPP $\beta$ (Figure 2B) were higher in $\mathrm{MCI}$ and AD patients than in the control subjects. In addition, for the control vs. MCI, the AUC for these two proteins was 0.9687 and 0.9068 , respectively (Figure 3 and Table 1 ), whereas, for the control vs. AD, the AUC were 0.9563 and 0.9185 , respectively. In addition, for MCI vs. AD, the AUC were 0.6351 and 0.5247 (Figure 3 and Table 1). For the control vs. MCI, the cut-off point for sAPP $\alpha$ was $1.39 \mathrm{ng} / \mathrm{mL}$ and $0.2639 \mathrm{ng} / \mathrm{mL}$ for sAPP $\beta$ (Table 1). For the control vs. AD, for sAPP $\alpha$ was $2.573 \mathrm{ng} / \mathrm{mL}$ and $0.2906 \mathrm{ng} / \mathrm{mL}$ for sAPP $\beta$ (Table 1). For MCI vs. AD, for sAPP $\alpha$ was $8.846 \mathrm{ng} / \mathrm{mL}$ and $0.6364 \mathrm{ng} / \mathrm{mL}$ for sAPP $\beta$ (Table 1). 

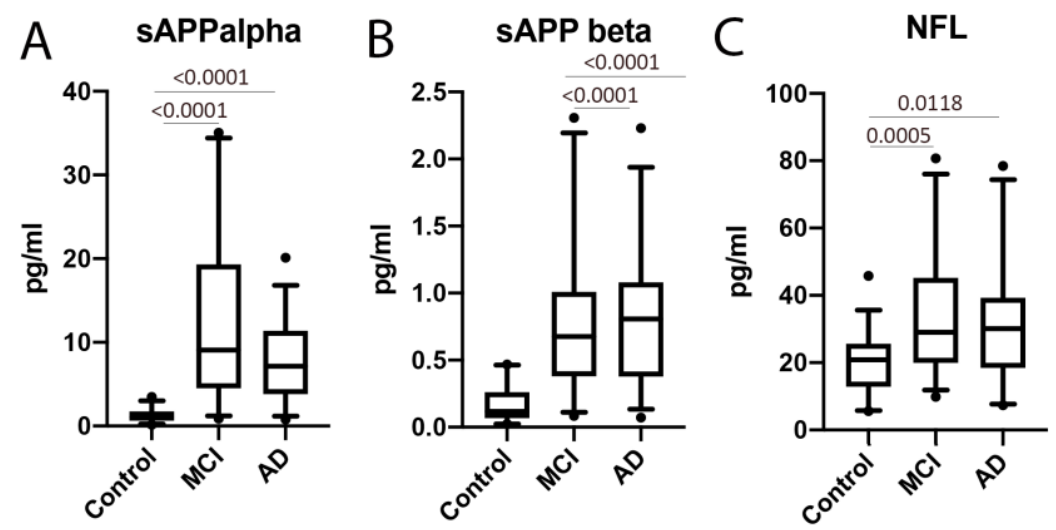

Figure 2. Soluble amyloid precursor proteins (APP) ( $\alpha$ and $\beta$ ) and neurofilament light chains were elevated in the serum of MCI and AD patients compared to the control. Protein levels in $\mathrm{pg} / \mathrm{mL}$ for (A) $\operatorname{sAPP} \alpha,($ B $)$ sAPP $\beta$ and (C) neurofilament light (NfL). Soluble (s)APP $\alpha: n=35$ control, $31 \mathrm{MCI}$ and 32 AD. sAPP $\beta: n=27$ control, $31 \mathrm{MCI}$ and 30 AD. NfL: $n=32$ control, $32 \mathrm{MCI}$ and $28 \mathrm{AD}$. Box and whiskers are shown for the 5 th and 95 th percentiles.
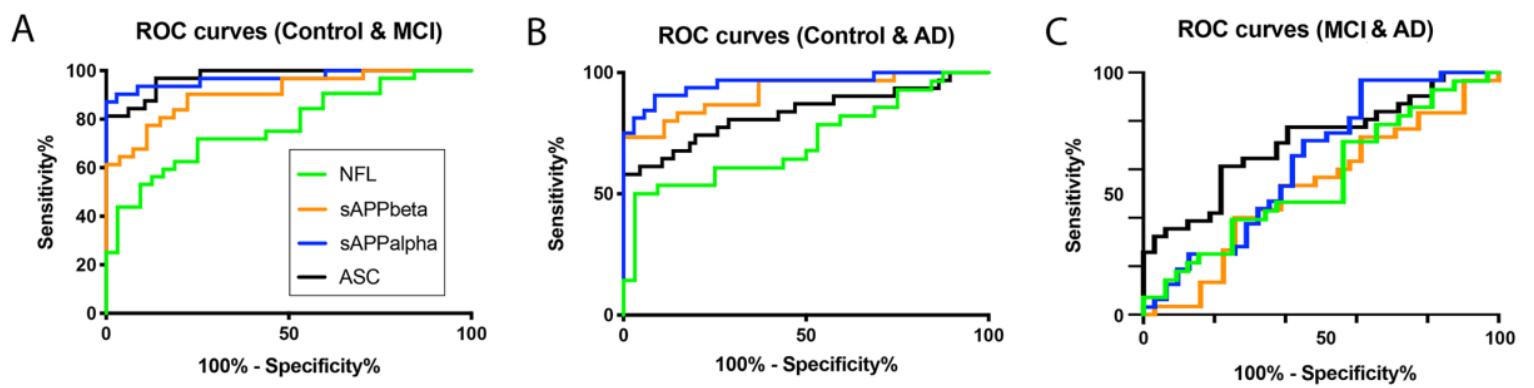

Figure 3. ASC is a promising serum biomarker of MCI. Receiver operator characteristic (ROC) curves for NfL (green), sAPP $\beta$ (orange), sAPP $\alpha$ (blue) and ASC (black). (A) Control vs. MCI, (B) control vs. $\mathrm{AD}$ and $(\mathrm{C}) \mathrm{MCI}$ vs. AD.

In comparison, for the control vs. MCI, the cut-off point for ASC was $264.9 \mathrm{pg} / \mathrm{mL}$ with $100 \%$ sensitivity and $74 \%$ specificity, while sAPP $\alpha$ had a cut-off point of $1.39 \mathrm{ng} / \mathrm{mL}$ with $97 \%$ sensitivity and $74 \%$ specificity, and sAPP $\beta$ had a cut-off point of $0.2639 \mathrm{ng} / \mathrm{mL}$ with $90 \%$ sensitivity and $78 \%$ specificity (Table 2).

For the control vs. AD, the cut-off point for ASC was $258.7 \mathrm{pg} / \mathrm{mL}$ with $81 \%$ sensitivity and $71 \%$ specificity, while sAPP $\alpha$ had a cut-off point of $2.573 \mathrm{ng} / \mathrm{mL}$ with $91 \%$ sensitivity and $91 \%$ specificity, and sAPP $\beta$ had a cut-off point of $0.2906 \mathrm{ng} / \mathrm{mL}$ with $83 \%$ sensitivity and $81 \%$ specificity (Table 2 ).

For MCI vs. AD, the cut-off point for ASC was $560.0 \mathrm{pg} / \mathrm{mL}$ with $71 \%$ sensitivity and $63 \%$ specificity, while sAPP $\alpha$ had a cut-off point of $8.846 \mathrm{ng} / \mathrm{mL}$ with $72 \%$ sensitivity and $55 \%$ specificity, and sAPP $\beta$ had a cut-off point of $0.6364 \mathrm{ng} / \mathrm{mL}$ with $60 \%$ sensitivity and $45 \%$ specificity (Table 2 ).

\section{4. $M C I, A D$ and $N f L$}

Additionally, we compared the serum protein levels of ASC to NfL. When comparing the levels of NfL in the control and MCI patients, we found that the protein levels of NfL were higher in MCI patients than in the control subjects (Figure 2). The AUC for NfL was 0.7734 (Figure 3 and Table 1), whereas, for ASC, it was 0.974, as above stated (Table 1). The cut-off point for NfL was $24.15 \mathrm{pg} / \mathrm{mL}$, with a sensitivity of $72 \%$ and a specificity of $75 \%$ (Table 2 ). In comparison, for the control vs. AD, the AUC for NfL was 0.7165 , and the cut-off point was $21.48 \mathrm{pg} / \mathrm{mL}$, with $64 \%$ sensitivity and $56 \%$ specificity (Table 2). However, no significant difference regarding NfL was found between MCI and AD. 


\subsection{Cluster Analysis Using ASC Protein Levels in Control, MCI and AD Patients}

Since ASC protein levels are present in the serum of control, MCI and AD patients, we pooled all the concentrations of ASC into one group and performed a cluster analysis. Accordingly, we found three different clusters using a Gaussian Mixture Modeling method (Figure 4A) consistent with the three different cohorts of patients present (control, MCI and AD). In addition, a cluster dendrogram was obtained using hierarchical clustering, in which three groups were also identified (Figure 4B), which was further corroborated in a coordinate plot (Figure 4C). Thus, these findings indicate that ASC protein levels in the serum can be used to stratify patients among the control, MCI and AD cohorts.
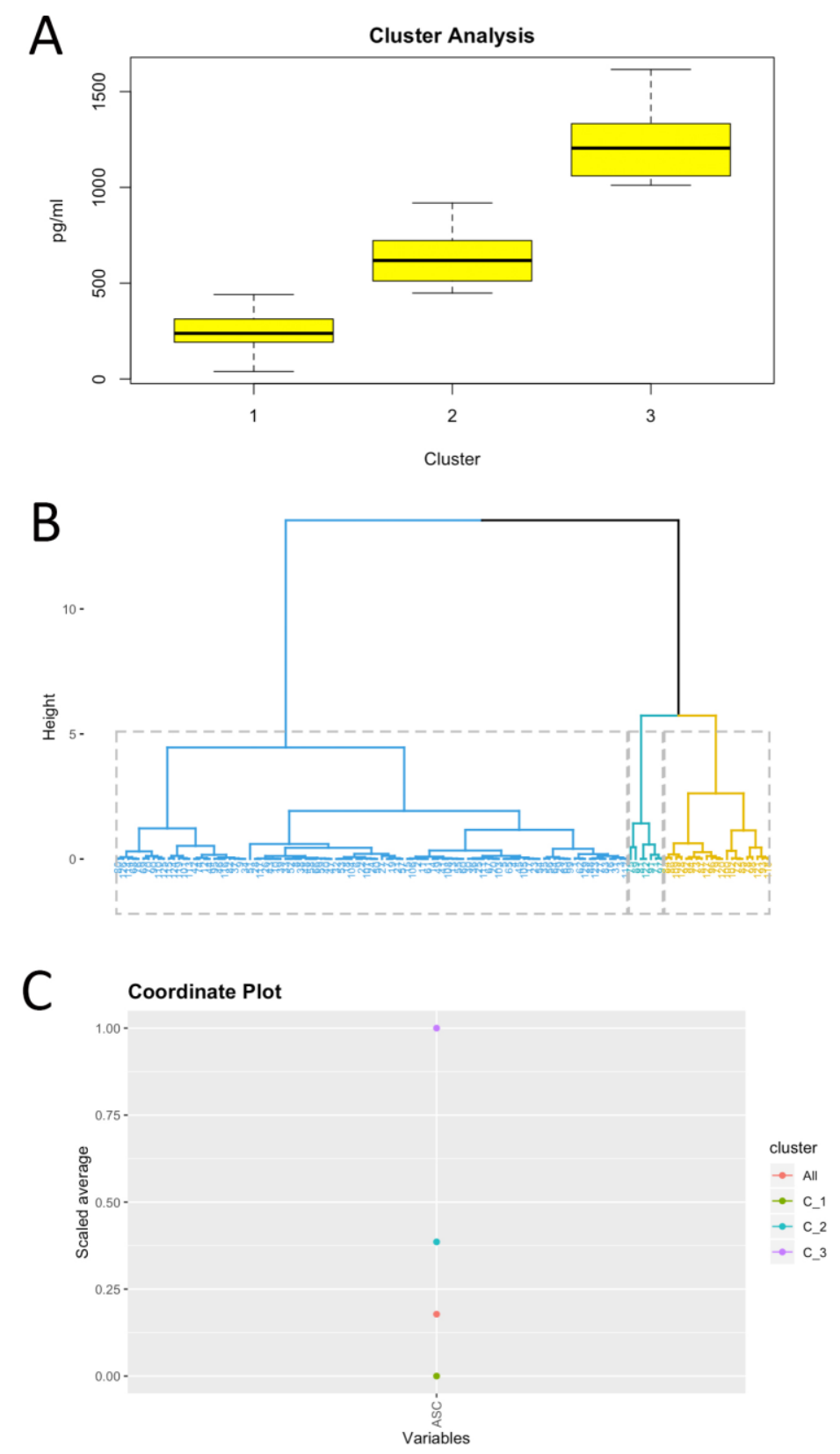

Figure 4. Clustering analysis based on serum ASC protein levels. Clustering using Gaussian Mixture Modeling (A), cluster dendrogram using hierarchical clustering (B) and coordinate plot (C).

\section{Discussion}

In this study, we provide evidence that the inflammasome signaling protein ASC may serve as a biomarker of MCI and AD. ASC and IL-18 were both significantly elevated in the serum of MCI 
patients when compared to controls, whereas ASC protein levels were also higher in the serum of MCI patients when compared to AD patients. However, there was no statistically significant difference between the levels of IL-18 in AD vs. the control subject. Thus, of all the inflammasome signaling proteins studied (ASC and IL-18), ASC was the protein that presented the best characteristics for a biomarker, including an AUC of 0.974 for the control vs. MCI, 0.8328 for the control vs. AD and 0.7157 for MCI vs. AD.

Importantly, due to the contribution of the inflammasome to inflammaging [17-19], we hypothesize that ASC would be a better monitoring biomarker than SAPP $\alpha / \beta$ and NfL for therapeutic interventions targeting the inflammatory response in patients with MCI. Since there is experimental evidence that $\operatorname{sAPP} \alpha / \beta$ are potential biomarkers for MCI and $\mathrm{AD}[11]$, we used these proteins as standards for the comparison of inflammasome proteins as novel biomarkers in these conditions. Our findings in the control vs. MCI groups, that ASC has an AUC of 0.974 compared to 0.9687 for $\operatorname{sAPP} \alpha, 0.9068$ for $\operatorname{sAPP} \beta$ and 0.7734 for NfL, suggest that ASC is a good biomarker comparable to more traditional biomarkers of MCI, such as sAPP $\alpha / \beta$ and NfL. Similar results, were found when comparing the control vs. AD. However, when comparing MCI vs. AD, ASC had an AUC of 0.7157, sAPP $\alpha$ 0.6351, sAPP $\beta 0.5247$ and $\mathrm{NfL}$ had an AUC of 0.5569 , suggesting that, when differentiating $\mathrm{MCI}$ vs. AD, ASC is a more reliable serum biomarker.

Interestingly, the levels of ASC were higher in MCI patients than in AD patients. The reason for this decrease in ASC as patients transition from MCI into AD is currently under investigation. However, this is consistent with our previous work on innate immunity and AD, in which retinoic acid-inducible gene-I (RIG-I) expression was also higher in the temporal cortex and plasma of MCI patients [28].

Previous studies have linked inflammation to cognitive impairment [29-33]. A few studies have noted the importance of the C-reactive protein (CRP), a well-studied biomarker of systemic inflammation, to cognitive impairment. High levels of CRP were associated with neuroinflammation and the diagnosis of $\mathrm{MCI}$ in patients who had lower scores on executive function and attention tests [32-34]. These findings further support the idea that inflammation plays a major role in the development of neurodegeneration in older populations. Recent evidence suggests that the aged brain has a heightened and chronic inflammatory state, which is referred to as inflammaging. Studies in rodents have shown that the activation of the inflammasome contributes to inflammaging of the central nervous system [17-19]. Changes in microglial activation have been associated with cognitive impairments in aging nonhuman primates that may contribute to inflammaging [35]. However, although several studies have provided evidence that links inflammation to neurodegeneration, the underlying pathomechanisms attributed to cognitive decline remain to be resolved.

Increased inflammasome protein expression may be associated with other comorbidities that are typical of aging patients. Thus, further studies with better-controlled and stratified patient populations are needed to better characterize inflammasome proteins as biomarkers for the early detection of MCI and AD. In addition, future studies will focus on patients with certain lifestyle parameters that could help stratify different patient populations. For instance, caloric restriction has been shown to modulate genes related to stress and the immune response in the aging brains of mice [36].

We have previously shown that inflammasome proteins can be used as biomarkers of the inflammatory response present in traumatic brain injury [22,37], multiple sclerosis [24], stroke [23] and depression [25]. Here we extend these findings and show that increased inflammasome protein expression occurs in $\mathrm{MCI}$ and $\mathrm{AD}$ subjects. These findings have important implications for the development of a biomarker panel that may aid physicians in the early detection and diagnosis of $\mathrm{MCI}$ and $\mathrm{AD}$. Moreover, the cluster analysis carried in this study indicates that the protein levels of ASC in the serum may be used to stratify patients into three distinct groups-namely, healthy, MCI and AD. Therefore, this study highlights the involvement of ASC in the pathology of MCI and AD. These findings are consistent with animal models that show that inflammasomes, such as the NLRP1 and NLRP3 inflammasomes, play an important role in AD pathology [38-41]. 
Moreover, despite ASC being an important marker of the inflammatory component in a variety of diseases or conditions, such as multiple sclerosis, [24] stroke, [23] depression [25] or brain injury [37], how much of an inflammatory component is present in a disease differs among diseases. We believe that the degree in the inflammatory component is marked by the difference in ASC levels between healthy and affected individuals. Thus, the greater the difference, the greater the contribution of ASC to a particular disease. In this study, the difference in ASC protein levels between the control and $\mathrm{MCI}$ is greater than between the control and AD. Thus, we hypothesize that ASC is a more significant inflammatory contributor to the pathology of MCI than AD. Moreover, future studies will look at the biomarker role of ASC on other neurodegenerative diseases, such as Parkinson's disease.

It is important to consider that samples used in this study came from patients that presented several comorbidities that could also contribute to the heightened inflammatory response presented here. Thus, in future studies, we will analyze patients with less comorbidities that could interfere with the analysis. However, despite the comorbidities, since this study was powered for a prevalence of $\mathrm{AD}$ and $\mathrm{MCI}$ and not the comorbidities, we were able to identify a difference between MCI and AD patients. Furthermore, we carried a binomial logistic regression model to test the odds of patients having MCI or AD based on the levels of ASC, and we determined that the odds of patients having MCI (estimate: $0.022628, p=0.000105$ ) or $\mathrm{AD}$ (estimate: $0.011559, p=1.28 \times 10^{-5}$ ) increased with higher levels of ASC in the serum, thus supporting the involvement of ASC in MCI and AD in this study, regardless of the comorbidities that patients presented. In addition, due to the challenges of diagnosing patients with $\mathrm{AD}$, it is possible that some patients identified as MCI may actually have had AD. Thus, future studies will use better-stratified patients and will aim to correlate the levels of inflammasome proteins with disease severity. These studies will also include a more thorough characterization of the cohort of patients using a battery of neuropsychological tests, as well as magnetic resonance imaging, where the degree of brain atrophy can be quantified and then correlated with the protein levels of ASC. In addition, we will measure the protein levels of ASC, A $\beta$, T-tau and phospho-tau in the CSF to better understand the relationship between ASC and A $\beta$, since these two proteins form a complex that is detrimental in mice [26,27]. Furthermore, we will determine whether isolated ASC specks are better biomarkers of AD pathology.

We have previously shown that, in healthy individuals, ASC and IL-18 are higher in the serum of humans over the age of 45 years old. In addition, we have shown that the levels of ASC were higher in Caucasians than in Blacks and Hispanics. Moreover, the protein levels of IL-18 were also higher in Caucasians than in Blacks [19]. In the present investigation, similar numbers of males and females were used for all groups, and the way race was reported in the $\mathrm{MCI}$ group did not allow for comparison between races and the diagnoses of MCI/AD. In this study, all patients were above the age of 50 in the control and $\mathrm{MCI}$ groups and 47 in the AD group. Thus, since no changes in the serums of patients above the age of 45 have been found for ASC and IL-18 in healthy subjects, we do not anticipate that the effects seen in this study are the result of age, but are, instead, due to the results of $\mathrm{MCI} / \mathrm{AD}$ pathology. However, logistic regression analyses that included age and the levels of ASC in the serum indicated that, as age and ASC levels increased, so did the odds of developing MCI and $\mathrm{AD}$ (data not shown). Therefore, since $\mathrm{AD}$ tends to occur later in life than $\mathrm{MCI}$, current studies are looking into the effects of these proteins, with careful standards for patient selection, including patients with $\mathrm{MCI}$ and $\mathrm{AD}$ that are in the same age range and patients with $\mathrm{AD}$ in which the disease severity is known. Unfortunately, in this study, the samples available were not characterized with regards to disease severity but based on physicians' diagnoses of AD.

Importantly, it has been shown that ASC fibrils bind to A $\beta$ and that microglia recognize this ASC/A $\beta$ complex, resulting in pyroptotic cell death. In addition, extracellular ASC specks may be taken up by microglia, leading to NLRP3 inflammasome activation [26]. Thus, it is possible that the levels of ASC present in the serum play a key role in the pathology of AD by binding to A $\beta$, further contributing to the deleterious effects associated with neuroinflammation in AD. In addition, the neutralization of ASC with a monoclonal antibody resulted in decreased A $\beta$ pathology in a mouse model of AD [27], 
an approach that previously has been shown to improve outcomes following CNS injuries [42-47]. Thus, current studies are underway to identify which form(s) of ASC (monomer, ASC fibril and ASC speck) is present in the serum of MCI and AD patients and to determine if any of these ASC forms are bound to A $\beta$. In summary, our study demonstrates that ASC may be used to differentiate inflammation linked to MCI and AD from age-associated inflammation in the elderly population and show that ASC is a promising biomarker for the diagnosis of these neurodegenerative conditions.

\section{Materials and Methods}

\subsection{Participants}

Samples were purchased from BioIVT (Hicksville, NY, USA). Sample donors were enrolled in the study Prospective Collection of Samples for Research sponsored by SeraTrials, LLC, with IRB number 20170439. Samples were obtained after informed consent. Here, we analyzed serum samples from 72 normal male (36 donors) and female (36) donors in the age range of 50 to 70 . Normal donors presented no comorbidities. In addition, we analyzed the serum from 32 male ( 16 donors) and female (16) patients diagnosed with MCI in the age range of 50 to 91 (Table 3) and with AD (22 males and 10 females) in the age range of 47 to 87 (Table 4). In the control group, 20 patients were Caucasian, 32 were Black, 19 were Hispanic and 1 was reported as Other. In the MCI group, 31 patients were reported as Caucasian, and 1 was reported as Caucasian/Japanese. In the MCI group, no distinction or stratification was done between Hispanics and Caucasians. In the AD group, 20 patients were Caucasian, 8 were Black and 4 were Hispanic (some Hispanics were also reported as Caucasians). Patients were classified according to their Atherosclerosis Risk in Communities magnetic resonance imaging (ARIC MRI) cognitive function scores. The scale was developed as part of the Atherosclerosis Risk in Communities (ARIC) study that recruited middle-aged individuals who underwent magnetic resonance imaging (MRI) to evaluate the risk factors of vascular problems in these individuals [48]. Cognitive testing was evaluated using the Delayed Word Recall Test, the Digit Symbol Subtest of the Wechsler Adult Intelligence Scale-Revised (WAIS-R) test and the Controlled Oral Word Association (or Word Fluency) Test of the Multilingual Aphasia Examination [49].

\subsection{Simple Plex Assay}

Analysis of inflammasome proteins (ASC and IL-18) and NfL protein concentration in the serum samples from $\mathrm{MCI}, \mathrm{AD}$ and controls were performed using the Ella System (Protein Simple, San Jose, CA, USA), as described in $[24,50]$.

\subsection{MSD Multi-SPOT sAPP $\alpha / s A P P \beta$ Assay}

Protein levels of soluble APP $\alpha$ and $\beta(\operatorname{sAPP} \alpha / \mathrm{sAPP} \beta)$ were measured using the MSD 96-well Multi-Spot sAPP $\alpha / \mathrm{sAPP} \beta$ Assay according to the manufacturer's instructions (Meso Scale Discovery, Rockville, MD, USA) and read on the MESO Quickplex SQ 120 instrument (Meso Scale Discovery, Rockville, MD, USA). Briefly, the plate was coated with Blocker A solution prior to adding the samples and calibrators, followed by addition of the detection antibody and, ultimately, the reading of the plate in the MESO Quickplex SQ 120 instrument. 
Table 3. Patients with MCI used in the study. ARIC MRI: Atherosclerosis Risk in Communities magnetic resonance imaging.

\begin{tabular}{|c|c|c|c|c|c|}
\hline Age & Gender & Race & Diagnosis & Medications & Historical Test \\
\hline 83 & Male & Caucasian & $\begin{array}{l}\text { Mild Cognitive Impairment (MCI), } \\
\text { Prostate Cancer, Methicillin Resistant } \\
\text { Staphylococcus Aureus Infection, } \\
\text { Hyperlipidemia (HLD), Hypertension } \\
\text { (HTN), Diverticulitis, Amnesia }\end{array}$ & $\begin{array}{l}\text { Omega } 31000 \text { mg, Plavix } 75 \text { mg, Toprol } \\
50 \text { mg, Vitamin B12-Folic Acid 0.5-1 } \\
\text { mg, Vitamin D } 400 \text { IU, Zetia } 10 \text { mg }\end{array}$ & $\begin{array}{l}\text { ARIC MRI Cognitive Function } \\
\text { Score }=18 \text { (20 February 2018) }\end{array}$ \\
\hline 81 & Female & Caucasian & $\begin{array}{l}\text { Mild Cognitive Impairment (MCI), } \\
\text { Type } 2 \text { Diabetes, Hypercholesterolemia }\end{array}$ & $\begin{array}{c}\text { Aspirin } 81 \mathrm{mg} \text {, Gabapentin } 100 \mathrm{~m} \text {, } \\
\text { Eliquis } 2.5 \mathrm{mg} \text {, Ranitidine } 150 \mathrm{mg} \text {, } \\
\text { Aricept } 10 \mathrm{mg}\end{array}$ & $\begin{array}{l}\text { ARIC MRI Cognitive Function } \\
\text { Score = } 18 \text { (22 May 2018) }\end{array}$ \\
\hline 62 & Male & Caucasian & $\begin{array}{l}\text { Mild Cognitive Impairment (MCI), } \\
\text { Type } 2 \text { Diabetes, Hypertension (HTN), } \\
\text { Hyperlipidemia (HLD), Asthma }\end{array}$ & $\begin{array}{c}\text { Omeprazole } 20 \mathrm{mg} \text {, Benicar 40-12.5 } \\
\text { mg, Metformin HCL1 } 500 \mathrm{mg}, \\
\text { Glucotrol XL } 5 \mathrm{mg} \text {, Singulair } 10 \mathrm{mg} \text {, } \\
\text { Clobetasol Propionate 0.05\%, Glipizide } \\
5 \mathrm{mg} \text {, Advair Diskus } 250 / 50 \mu \mathrm{g} \text {, Crestor } \\
10 \mathrm{mg} \text {, Ipratropium-Albuterol } \\
0.5-2.5 \mathrm{mg} / 3 \mathrm{~mL} \text {, Ventolin HFA } 108 \mu \mathrm{g}\end{array}$ & $\begin{array}{l}\text { ARIC MRI Cognitive Function } \\
\text { Score = } 30 \text { (15 May 2018) }\end{array}$ \\
\hline 69 & Female & Caucasian & $\begin{array}{c}\text { Mild Cognitive Impairment (MCI), } \\
\text { Asthma, Chronic Obstructive } \\
\text { Pulmonary Disease (COPD), } \\
\text { Hypertension (HTN) }\end{array}$ & $\begin{array}{l}\text { Alendronate } 70 \mathrm{mg} \text {, Meclizine } 12.5 \mathrm{mg} \text {, } \\
\text { Prozac } 40 \mathrm{mg} \text {, Seroquel } 50 \mathrm{mg} \text {, Trilipix } \\
54 \mathrm{mg}\end{array}$ & $\begin{array}{l}\text { ARIC MRI Cognitive Function } \\
\text { Score = } 21 \text { (30 May 2018) }\end{array}$ \\
\hline 75 & Male & Caucasian & $\begin{array}{l}\text { Mild Cognitive Impairment (MCI), } \\
\text { Colon Cancer }\end{array}$ & $\begin{array}{l}\text { Vitamin B12 } 2500 \text { IU, Avastin, Adrucil, } \\
\text { Amoxicillin } 500 \text { mg, Lisinopril } 20 \text { mg, } \\
\text { Metformin HCL1 } 500 \text { mg }\end{array}$ & $\begin{array}{l}\text { ARIC MRI Cognitive Function } \\
\text { Score = } 12 \text { (27 March 2018) }\end{array}$ \\
\hline 72 & Male & Caucasian & $\begin{array}{c}\text { Mild Cognitive Impairment (MCI), } \\
\text { Benign Prostatic Hyperplasia (BPH), } \\
\text { Lumbar Spondylosis, Barrett's } \\
\text { Esophagus, Atrial Ectopy, } \\
\text { Hypertension (HTN) }\end{array}$ & $\begin{array}{l}\text { Tamsulosin HCL1 } 0.4 \text { mg, Finasteride } 5 \\
\text { mg, Multivitamin, Fish Oil } 1000 \text { mg, } \\
\text { Viagra } 100 \text { mg, Tramadol HCL1 } 50 \text { mg }\end{array}$ & $\begin{array}{l}\text { ARIC MRI Cognitive Function } \\
\text { Score = } 15 \text { (10 May 2018) }\end{array}$ \\
\hline 64 & Male & Caucasian & $\begin{array}{l}\text { Mild Cognitive Impairment (MCI), } \\
\text { Type } 2 \text { Diabetes, Hypertension (HTN), } \\
\text { Hypercholesterolemia, Benign } \\
\text { Prostatic Hyperplasia (BPH) }\end{array}$ & $\begin{array}{l}\text { Zolpidem } 10 \mathrm{mg} \text {, Cialis } 5 \mathrm{mg} \text {, Aspirin } \\
81 \mathrm{mg} \text {, Tamsulosin } 0.4 \mathrm{mg}, \\
\text { Rosuvastatin } 20 \mathrm{mg} \text {, Metformin } 500 \mathrm{mg}\end{array}$ & $\begin{array}{l}\text { ARIC MRI Cognitive Function } \\
\quad \text { Score }=34 \text { (4 April 2018) }\end{array}$ \\
\hline
\end{tabular}


Table 3. Cont

\begin{tabular}{|c|c|c|c|c|c|}
\hline Age & Gender & Race & Diagnosis & Medications & Historical Test \\
\hline 84 & Female & Caucasian & $\begin{array}{c}\text { Mild Cognitive Impairment (MCI), } \\
\text { Hypertension (HTN), Psychoses, } \\
\text { Cellulitis, Mitral Valve Prolapse (MVP), } \\
\text { Hyperlipidemia (HLD) }\end{array}$ & $\begin{array}{l}\text { Simvastatin } 20 \mathrm{mg} \text {, Potassium Chloride } \\
10 \mathrm{mEq} \text {, Amlodipine Besylate } 2.5 \mathrm{mg} \text {, } \\
\text { Dutasteride } 0.5 \mathrm{mg} \text {, Losartan } \\
\text { Potassium } 100 \mathrm{mg} \text {, Aspirin } 81 \mathrm{mg} \text {, } \\
\text { Furosemide } 20 \mathrm{mg} \text {, Potassium Chloride } \\
10 \mathrm{mEq} \text {, Avodart } 0.4 \mathrm{mg} \text {, Amlodipine } \\
\text { Besylate } 2.5 \mathrm{mg} \text {, Ramipril } 10 \mathrm{mg}\end{array}$ & $\begin{array}{l}\text { ARIC MRI Cognitive Function } \\
\quad \text { Score }=8 \text { (10 May 2018) }\end{array}$ \\
\hline 68 & Female & Caucasian & $\begin{array}{l}\text { Mild Cognitive Impairment (MCI), } \\
\text { Multiple Sclerosis }\end{array}$ & Tysabri, Lexapro, Gabapentin & $\begin{array}{l}\text { ARIC MRI Cognitive Function } \\
\text { Score }=15 \text { (6 April 2018) }\end{array}$ \\
\hline 69 & Female & Caucasian & $\begin{array}{c}\text { Mild Cognitive Impairment (MCI), } \\
\text { Hypercholesterolemia, Hypertension } \\
\text { (HTN), Type } 2 \text { Diabetes, Premature } \\
\text { Ventricular Contraction }\end{array}$ & $\begin{array}{l}\text { Crestor } 5 \text { mg, Omega 3, Zolpidem } \\
\text { Tartrate } 5 \mathrm{mg} \text {, Glucosamine } 1500 \mathrm{mg} \text {, } \\
\text { Fiber, Calcium, Multivitamin, Zyrtec, } \\
\text { Chlordiazepoxide-Clidinium } 2.5-5 \mathrm{mg} \text {, } \\
\text { Valacyclovir } 500 \mathrm{mg} \text {, Lisinopril } 10 \mathrm{mg} \text {, } \\
\text { Janumet } 50-500 \mathrm{mg} \text {, Metoprolol } \\
\text { Succinate } 25 \mathrm{mg} \text {, Levothyroxine } \\
\text { Sodium } 100 \mu \mathrm{g} \text {, Rosuvastatin Calcium } \\
5 \mathrm{mg} \text {, Omega 3-Acid Ethyl Esters } 1 \mathrm{~g}, \\
\text { Trazodone } 50 \mathrm{mg}\end{array}$ & $\begin{array}{l}\text { ARIC MRI Cognitive Function } \\
\text { Score = } 33 \text { (1 May 2018) }\end{array}$ \\
\hline 50 & Female & Caucasian & $\begin{array}{c}\text { Mild Cognitive Impairment (MCI), } \\
\text { Hypercholesterolemia }\end{array}$ & None & $\begin{array}{l}\text { ARIC MRI Cognitive Function } \\
\text { Score }=30 \text { (24 April 2018) }\end{array}$ \\
\hline 78 & Male & Caucasian & Mild Cognitive Impairment (MCI) & $\begin{array}{l}\text { Zaleplon } 10 \text { mg, Lorazepam } 1 \mathrm{mg} \text {, } \\
\text { Plavix } 75 \text { mg, Aspirin, Allopurinol } 300 \\
\text { mg, Levothyroxine Sodium 125mcg, } \\
\text { Atorvastatin Calcium } 20 \text { mg, } \\
\text { Metformin HCLl } 1000 \mathrm{mg}, \\
\text { Pantoprazole Sodium } 40 \mathrm{mg}\end{array}$ & $\begin{array}{l}\text { ARIC MRI Cognitive Function } \\
\text { Score }=24 \text { (27 April 2018) }\end{array}$ \\
\hline
\end{tabular}


Table 3. Cont

\begin{tabular}{|c|c|c|c|c|c|}
\hline Age & Gender & Race & Diagnosis & Medications & Historical Test \\
\hline 77 & Male & Caucasian & $\begin{array}{l}\text { Mild Cognitive Impairment (MCI), } \\
\text { Hypertension (HTN), Hyperlipidemia } \\
\text { (HLD), Vitamin D Deficiency }\end{array}$ & $\begin{array}{l}\text { Aciphex } 20 \text { mg, Citric Acid-D-Gluconic } \\
\text { Acid, Avodart } 0.5 \mathrm{mg} \text {, Cozaar } 100 \mathrm{mg} \text {, } \\
\text { Ranitidine Acid Reducer } 75 \mathrm{mg} \text {, } \\
\text { Polyethylene Glycol, MiraLAX, } \\
\text { Symbicort } 4.5-80 \mu \mathrm{\mu g} \text {, Proair } 108 \mu \mathrm{g}, \\
\text { Ipratropium Bromide } 0.03 \% \text {, Prevacid } \\
15 \mathrm{mg} \text {, Losartan Potassium } 100 \mathrm{mg}, \\
\text { Levocetirizine Dihydrochloride } 5 \mathrm{mg} \text {, } \\
\text { Cialis } 5 \mathrm{mg} \text {, Albuterol, Rabeprazole } \\
\text { Sodium } 20 \mathrm{mg} \text {, Atorvastatin Calcium } \\
20 \mathrm{mg}\end{array}$ & $\begin{array}{l}\text { ARIC MRI Cognitive Function } \\
\quad \text { Score }=24 \text { (9 May 2018) }\end{array}$ \\
\hline 73 & Female & Caucasian & $\begin{array}{l}\text { Mild Cognitive Impairment (MCI), } \\
\text { Hypercholesterolemia, } \\
\text { Hypothyroidism, Hypothyroidism, } \\
\text { Gastroesophageal Reflux Disease } \\
\text { (GERD), Vitamin D Deficiency, } \\
\text { Hypertension (HTN) }\end{array}$ & 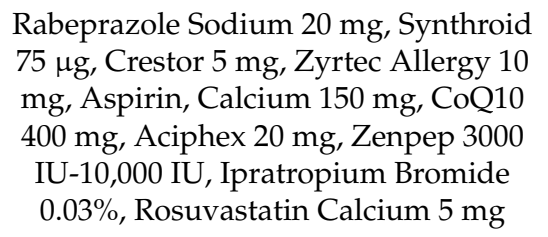 & $\begin{array}{l}\text { ARIC MRI Cognitive Function } \\
\text { Score = } 37 \text { (9 May 2018) }\end{array}$ \\
\hline 71 & Male & Caucasian & $\begin{array}{l}\text { Mild Cognitive Impairment (MCI), } \\
\text { Dyslipidemia, Valvular Heart Disease, } \\
\text { Hypertension (HTN), Hyperlipidemia } \\
\text { (HLD), Aortic Aneurysm, Ulcerative } \\
\text { Colitis (UC) }\end{array}$ & $\begin{array}{l}\text { Epipen, Metoprolol Succinate ER } 50 \\
\text { mg, Zyrtec, Montelukast, Pepcid, } \\
\text { Tramadol } 50 \mathrm{mg} \text {, Diazepam } 5 \mathrm{mg}, \\
\text { Metamucil } 48.57 \% \text {, Aspirin } 81 \mathrm{mg}, \\
\text { Plavix } 75 \mathrm{mg} \text {, Nexium } 40 \mathrm{mg} \text {, Lipitor } \\
10 \mathrm{mg} \text {, Asacol } 800 \mathrm{mg}\end{array}$ & $\begin{array}{l}\text { ARIC MRI Cognitive Function } \\
\text { Score = } 24 \text { (10 May 2018) }\end{array}$ \\
\hline 74 & Female & Caucasian & $\begin{array}{c}\text { Mild Cognitive Impairment (MCI), } \\
\text { Asthma, Chronic Obstructive } \\
\text { Pulmonary Disease (COPD), Type } 2 \\
\text { Diabetes, Hypercholesterolemia, } \\
\text { Congestive Heart Failure (CHF), } \\
\text { Hypothyroidism }\end{array}$ & $\begin{array}{c}\text { Levothyroxine } 75 \mathrm{mg} \text {, Metformin } \\
500 \mathrm{mg} \text {, Losartan } 100 \mathrm{mg} \text {, Symbicort, } \\
\text { Proventil, Calcium, Vitamin D3, Zyrtec } \\
10 \mathrm{mg}\end{array}$ & $\begin{array}{l}\text { ARIC MRI Cognitive Function } \\
\text { Score = } 30 \text { (11 May 2018) }\end{array}$ \\
\hline
\end{tabular}


Table 3. Cont.

\begin{tabular}{|c|c|c|c|c|c|}
\hline Age & Gender & Race & Diagnosis & Medications & Historical Test \\
\hline 75 & Male & Caucasian & $\begin{array}{c}\text { Mild Cognitive Impairment (MCI), } \\
\text { Neuropathy, Benign Prostatic } \\
\text { Hyperplasia (BPH), Hypertension } \\
\text { (HTN), Rheumatoid Arthritis (RA), } \\
\text { Sjogren's Syndrome, Glaucoma, } \\
\text { Allergic Rhinitis, Nasal Obstruction, } \\
\text { Type 2 Diabetes }\end{array}$ & 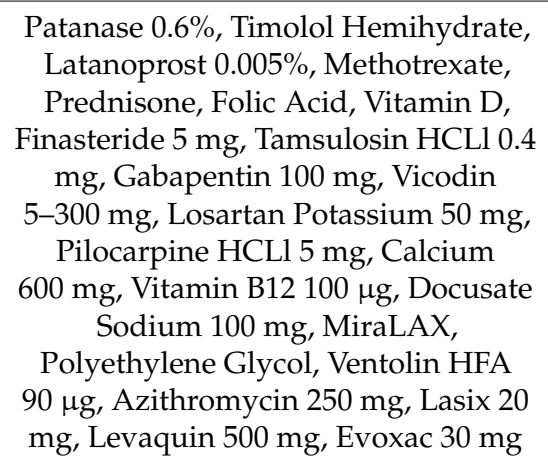 & $\begin{array}{l}\text { ARIC MRI Cognitive Function } \\
\text { Score = Refused (18 May 2018) }\end{array}$ \\
\hline 75 & Male & Caucasian & $\begin{array}{l}\text { Mild Cognitive Impairment (MCI), } \\
\text { Hypercholesterolemia, Thyroid Disease }\end{array}$ & $\begin{array}{l}\text { Levothyroxine Sodium } 25 \mu \mathrm{g} \text {, Crestor } \\
\qquad 40 \mathrm{mg}\end{array}$ & $\begin{array}{l}\text { ARIC MRI Cognitive Function } \\
\text { Score = } 35 \text { (24 May 2018) }\end{array}$ \\
\hline 75 & Male & Caucasian & $\begin{array}{c}\text { Mild Cognitive Impairment (MCI), } \\
\text { Hypercholesterolemia, Age Related } \\
\text { Macular Degeneration (AMD), Erectile } \\
\text { Dysfunction (ED) }\end{array}$ & $\begin{array}{c}\text { Pravachol } 40 \text { mg, Ocuvite, } \\
\text { Viagra } 50 \mathrm{mg}\end{array}$ & $\begin{array}{l}\text { ARIC MRI Cognitive Function } \\
\text { Score }=31 \text { (19 February 2018) }\end{array}$ \\
\hline 75 & Female & Caucasian & $\begin{array}{c}\text { Mild Cognitive Impairment (MCI), } \\
\text { Type } 2 \text { Diabetes, Hypertension (HTN), } \\
\text { Dyslipidemia, Chronic Kidney Disease } \\
\text { (CKD), Pulmonary Nodule, } \\
\text { Hyperlipidemia (HLD) }\end{array}$ & $\begin{array}{l}\text { Metformin } 500 \mathrm{mg} \text {, Atorvastatin } \\
\text { Calcium } 20 \mathrm{mg} \text {, Cozaar } 100 \mathrm{mg} \text {, } \\
\text { Aspirin } 81 \mathrm{mg} \text {, Hydrochlorothiazide } \\
25 \mathrm{mg} \text {, Lipitor } 20 \mathrm{mg}\end{array}$ & $\begin{array}{l}\text { ARIC MRI Cognitive Function } \\
\text { Score = } 42 \text { (1 May 2018) }\end{array}$ \\
\hline 76 & Female & Caucasian & $\begin{array}{l}\text { Mild Cognitive Impairment (MCI), } \\
\text { Hyperlipidemia (HLD), Hypertension } \\
\text { (HTN), Gastroesophageal Reflux } \\
\text { Disease (GERD), Anxiety, } \\
\text { Hypothyroidism }\end{array}$ & $\begin{array}{l}\text { Donepezil HCL } 10 \mathrm{mg} \text {, Levothyroxine } \\
\text { Sodium } 50 \mu \mathrm{g} \text {, Tramadol HCL1 } 50 \mathrm{mg} \text {, } \\
\text { Atorvastatin Calcium } 20 \mathrm{mg} \text {, } \\
\text { Omeprazole } 20 \mathrm{mg} \text {, Losartan } \\
\text { Potassium } 50 \mathrm{mg} \text {, Aricept } 10 \mathrm{mg} \text {, Paxil } \\
20 \mathrm{mg} \text {, Namenda } 10 \mathrm{mg}\end{array}$ & $\begin{array}{l}\text { ARIC MRI Cognitive Function } \\
\text { Score = } 7 \text { (4 May 2018) }\end{array}$ \\
\hline
\end{tabular}


Table 3. Cont

\begin{tabular}{|c|c|c|c|c|c|}
\hline Age & Gender & Race & Diagnosis & Medications & Historical Test \\
\hline 76 & Male & Caucasian & $\begin{array}{l}\text { Mild Cognitive Impairment (MCI), } \\
\text { Hypertension (HTN), Type } 2 \text { Diabetes, } \\
\text { Peripheral Polyneuropathy, Benign } \\
\text { Prostatic Hyperplasia (BPH) }\end{array}$ & $\begin{array}{l}\text { Novolog, Lantus } 100 \mathrm{U} / \mathrm{mL} \text {, Metoprolol } \\
\text { Succinate } 25 \mathrm{mg} \text {, Tacrolimus, Terazosin } \\
\text { HCLL } 10 \mathrm{mg} \text {, CellCept } 250 \mathrm{mg} \text {, Aspirin } \\
81 \mathrm{mg} \text {, Allopurinol } 150 \mathrm{mg} \text {, } \\
\text { Atorvastatin Calcium } 10 \mathrm{mg} \text {, Losartan } \\
\text { Potassium } 100 \mathrm{mg}\end{array}$ & $\begin{array}{l}\text { ARIC MRI Cognitive Function } \\
\text { Score = } 28 \text { (15 May 2018) }\end{array}$ \\
\hline 67 & Female & Caucasian & $\begin{array}{l}\text { Mild Cognitive Impairment (MCI), } \\
\text { Asthma, Hypercholesterolemia }\end{array}$ & Crestor $40 \mathrm{mg}$, Omeprazole $20 \mathrm{mg}$ & $\begin{array}{l}\text { ARIC MRI Cognitive Function } \\
\text { Score }=40 \text { (7 May 2018) }\end{array}$ \\
\hline 56 & Female & $\begin{array}{l}\text { Caucasian/ } \\
\text { Japanese }\end{array}$ & Mild Cognitive Impairment (MCI) & Daily Vitamins, Aspirin 81 mg & $\begin{array}{l}\text { ARIC MRI Cognitive Function } \\
\text { Score = } 41 \text { ( } 8 \text { May 2018) }\end{array}$ \\
\hline 58 & Female & Caucasian & $\begin{array}{c}\text { Mild Cognitive Impairment (MCI), } \\
\text { Hyperlipidemia (HLD) }\end{array}$ & $\begin{array}{l}\text { Simvastatin } 20 \text { mg, Caltrate } 600 \\
\text { mg-Vitamin D } 800 \mathrm{IU} \text {, Vitamin D } 2000 \\
\text { IU, Ibuprofen } 800 \text { mg, Prolia } 60 \mathrm{mg} / \mathrm{mL}\end{array}$ & $\begin{array}{l}\text { ARIC MRI Cognitive Function } \\
\quad \text { Score }=42 \text { ( } 8 \text { May 2018) }\end{array}$ \\
\hline 75 & Female & Caucasian & $\begin{array}{c}\text { Mild Cognitive Impairment (MCI), AF, } \\
\text { Dyslipidemia, Hypertension (HTN), } \\
\text { Hypothyroidism }\end{array}$ & $\begin{array}{c}\text { Crestor } 10 \mathrm{mg} \text {, Armour Thyroid } 60 \mathrm{mg} \text {, } \\
\text { Ramipril } 5 \mathrm{mg} \text {, Hydrochlorothiazide } 25 \\
\text { mg, Promethium } 200 \mathrm{mg} \text {, Augmentin } \\
\text { 125-875 mg, Rosuvastatin Calcium } \\
10 \mathrm{mg}\end{array}$ & $\begin{array}{l}\text { ARIC MRI Cognitive Function } \\
\text { Score = } 31 \text { (11 May 2018) }\end{array}$ \\
\hline 84 & Female & Caucasian & $\begin{array}{l}\text { Mild Cognitive Impairment (MCI), } \\
\text { Venous Insufficiency, Hyperlipidemia } \\
\text { (HLD), Hypothyroidism, Parkinson's } \\
\text { Disease (PD), Mitral Valve Prolapse } \\
\text { (MVP), Anxiety }\end{array}$ & $\begin{array}{l}\text { Cipro } 500 \mathrm{mg} \text {, Ibuprofen } 800 \mathrm{mg} \text {, } \\
\text { Xanax } 0.5 \mathrm{mg} \text {, Fluconazole } 150 \mathrm{mg} \text {, } \\
\text { Carbidopa-Levodopa } 25-100 \mathrm{mg}, \\
\text { Potassium Chloride } 20 \mathrm{mEq}, \\
\text { Simvastatin } 20 \mathrm{mg} \text {, Furosemide } 40 \mathrm{mg} \text {, } \\
\text { Levothyroxine Sodium } 75 \mu \mathrm{g} \text {, Atenolol } \\
25 \mathrm{mg}, \text { Lasix, Aspirin } 81 \mathrm{mg}, \\
\text { Acetaminophen } 500 \mathrm{mg}\end{array}$ & $\begin{array}{l}\text { ARIC MRI Cognitive Function } \\
\text { Score = } 19 \text { (11 May 2018) }\end{array}$ \\
\hline 88 & N/A & Caucasian & $\begin{array}{l}\text { Mild Cognitive Impairment (MCI), } \\
\text { Hyperlipidemia (HLD), Peripheral } \\
\text { Vascular Disease, Hypertension (HTN), } \\
\text { Hyperlipidemia, Mild Intermittent } \\
\text { Asthma, Hypercholesterolemia, } \\
\text { Type } 2 \text { Diabetes }\end{array}$ & $\begin{array}{l}\text { Cozaar } 100 \text { mg, Crestor } 10 \text { mg, Aspirin, } \\
\text { Prilosec } 20 \text { mg, Amlodipine Besylate } 5 \\
\text { mg, D3 } 1000 \mathrm{IU} \text {, Vitamin C } 100 \mathrm{mg} \text {, } \\
\text { Multi for Him, Omeprazole } 20 \mathrm{mg}\end{array}$ & $\begin{array}{l}\text { ARIC MRI Cognitive Function } \\
\quad \text { Score }=8 \text { (22 May 2018) }\end{array}$ \\
\hline
\end{tabular}


Table 3. Cont

\begin{tabular}{|c|c|c|c|c|c|}
\hline Age & Gender & Race & Diagnosis & Medications & Historical Test \\
\hline 71 & Male & Caucasian & $\begin{array}{c}\text { Mild Cognitive Impairment (MCI), } \\
\text { Hypertension (HTN), } \\
\text { Hypercholesterolemia, Chronic Kidney } \\
\text { Disease (CKD), Palsy of Conjugate } \\
\text { Gaze, Short Term Memory, } \\
\text { Hyperlipidemia, Cervical Spondylosis, } \\
\text { Basal Cell Cancer (BCC), Complex } \\
\text { Partial Epileptic Seizure, Chronic } \\
\text { Tremor, Lumbosacral Radiculitis, } \\
\text { Allergic Rhinitis, Lumbar Arthritis, } \\
\text { Arthritis, Bilateral Hearing Loss }\end{array}$ & $\begin{array}{l}\text { Aspirin } 81 \mathrm{mg} \text {, Brimonidine } 0.15 \% \text {, } \\
\text { Cialis } 20 \mathrm{mg} \text {, Dexamethasone } 4 \mathrm{mg} / \mathrm{mL} \text {, } \\
\text { Donepezil } 5 \mathrm{mg} \text {, Fexofenadine } 180 \mathrm{mg} \text {, } \\
\text { Lamotrigine } 200 \mathrm{mg} \text {, Lisinopril } 5 \mathrm{mg} \text {, } \\
\text { Meloxicam } 15 \mathrm{mg} \text {, Pramipexole } 0.25 \\
\text { mg, Simvastatin } 40 \mathrm{mg} \text {, Virtussin } \\
10-100 \mathrm{mg} / 5 \mathrm{~mL}\end{array}$ & $\begin{array}{l}\text { ARIC MRI Cognitive Function } \\
\text { Score = } 44 \text { (24 May 2018) }\end{array}$ \\
\hline 86 & Male & Caucasian & $\begin{array}{l}\text { Mild Cognitive Impairment (MCI), } \\
\text { Hypertensive Heart and Renal Disease } \\
\text { with Congestive Heart Failure, Cyst } \\
\text { and Pseudocyst of Pancreas, Benign } \\
\text { Prostatic Hyperplasia (BPH), Type } 2 \\
\text { Diabetes, Chronic Kidney Disease } \\
\text { (CKD), Hypokalemia, Chronic Systolic } \\
\text { Heart Disease, Mitral Valve Prolapse } \\
\text { (MVP), Atrial Fibrillation (AF), } \\
\text { Hyperlipidemia, Sensorineural } \\
\text { Hearing Loss, Left Bundle Branch } \\
\text { Block, Pulmonary Hypertension } \\
\text { (HTN), Hyperparathyroidism }\end{array}$ & $\begin{array}{l}\text { Amlodipine } 5 \mathrm{mg} \text {, Glimepiride } 1 \mathrm{mg} \text {, } \\
\text { Nitroglycerin } 0.2 \mathrm{mg} \text {, Potassium } \\
\text { Chloride } 20 \mathrm{mEq} \text {, Warfarin } 2 \mathrm{mg}\end{array}$ & $\begin{array}{l}\text { ARIC MRI Cognitive Function } \\
\text { Score = } 48 \text { (17 May 2018) }\end{array}$ \\
\hline 91 & Female & Caucasian & $\begin{array}{l}\text { Mild Cognitive Impairment (MCI), } \\
\text { Type } 2 \text { Diabetes, Hypertension (HTN), } \\
\text { Hypercholesterolemia, Benign Prostate } \\
\text { Hyperplasia (BPH), Abdominal Aortic } \\
\text { Aneurysm, Atrial Fibrillation (AF) }\end{array}$ & $\begin{array}{c}\text { Amlodipine Besylate } 5 \mathrm{mg}, \\
\text { Atorvastatin Calcium } 40 \mathrm{mg}, \\
\text { Coumadin, Plavix } 75 \mathrm{mg} \text {, Toprol } 50 \mathrm{mg}\end{array}$ & $\begin{array}{l}\text { ARIC MRI Cognitive Function } \\
\text { Score = } 31 \text { (13 March 2018) }\end{array}$ \\
\hline 88 & Male & Caucasian & $\begin{array}{l}\text { Mild Cognitive Impairment (MCI), } \\
\text { Hypercholesterolemia, Melanoma, } \\
\text { Depression, Squamous Cell Carcinoma, } \\
\text { GERD, Hemorrhoids, TIA }\end{array}$ & $\begin{array}{c}\text { Trintellix } 10 \mathrm{mg} \text {, Aripiprazole } 2.5 \mathrm{mg} \text {, } \\
\text { Rosuvastatin } 20 \mathrm{mg} \text {, Modafinil } 200 \mathrm{mg}, \\
\text { Amphetamine } 20 \mathrm{mg} \text {, Namenda } 28 \mathrm{mg}, \\
\text { Esomeprazole } 20 \mathrm{mg} \text {, Lutein } 5 \mathrm{mg}, \\
\text { Vitamin D3 } 1000 \mathrm{IU} \text {, Aspirin } 81 \mathrm{mg}, \\
\text { Vitamin B12 }\end{array}$ & $\begin{array}{l}\text { ARIC MRI Cognitive Function } \\
\text { Score }=16 \text { (21 February 2018) }\end{array}$ \\
\hline
\end{tabular}


Table 4. Patients with AD used in this study.

\begin{tabular}{|c|c|c|c|c|}
\hline Gender & Age & Race & Diagnosis & Medications \\
\hline Male & 82 & Caucasian & $\begin{array}{c}\text { Alzheimer's Disease (AD), Gastroesophageal } \\
\text { Reflux Disease (GERD), Benign Prostatic } \\
\text { Hyperplasia (BPH), Sleep Apnea, Malignant Basal } \\
\text { Cell Neoplasm of Skin, Depression, Dermatitis, } \\
\text { Osteoarthritis (OA), Thrombocytopenia }\end{array}$ & $\begin{array}{c}\text { Aricept } 10 \mathrm{mg} \text {, B Complex } 1000.4 \mathrm{mg}, \\
\text { Doxazosin } 8 \mathrm{mg} \text {, Finasteride } 5 \mathrm{mg} \text {, Melatonin } \\
10 \mathrm{mg} \text {, Multivitamin } 9 \mathrm{mg} \text {, Omeprazole } 20 \mathrm{mg} \text {, } \\
\text { Sertraline, Simvastatin } 80 \mathrm{mg} \text {, Vitamin D3 } 2000 \\
\text { IU, Voltaren } 1 \%\end{array}$ \\
\hline Male & 87 & Caucasian & $\begin{array}{c}\text { Alzheimer's Disease (AD), Hypertension (HTN), } \\
\text { Hyperlipidemia, Dementia }\end{array}$ & $\begin{array}{l}\text { Cartia XT } 120 \text { mg, Prilosec } 20 \text { mg, Namenda } \\
\text { 28XL, Exelon Patch } 9.5 \text { mg, Paxil } 20 \text { mg }\end{array}$ \\
\hline Female & 84 & Caucasian & $\begin{array}{c}\text { Hypertension (HTN), Vitamin D Deficiency, } \\
\text { Hyperlipidemia (HLD), Skin Cancer, Anemia, } \\
\text { Alzheimer's Disease (AD) }\end{array}$ & $\begin{array}{l}\text { Cerefolin NAC 6-200 mg, Clopidogrel } \\
\text { Bisulfate } 75 \text { mg, Multivitamin, Galantamine } \\
\text { Hydrobromide ER } 16 \text { mg, Memantine } \\
\text { HCLHCL } 10 \text { mg, Vitamin D3, Zolpidem } \\
\text { Tartrate } 5 \text { mg, Iron } 325 \text { mg, Remeron } 15 \text { mg, } \\
\text { Plavix } 75 \text { mg }\end{array}$ \\
\hline Female & 76 & Caucasian & $\begin{array}{l}\text { Hyperlipidemia (HLD), Hypertension (HTN), } \\
\text { Gastroesophageal Reflux Disease (GERD), Anxiety, } \\
\text { Alzheimer's Disease (AD), Hypothyroidism }\end{array}$ & $\begin{array}{l}\text { Donepezil HCLHCL } 10 \text { mg, Levothyroxine } \\
\text { Sodium } 50 \mu \mathrm{g} \text {, Tramadol HCLHCL50 mg, } \\
\text { Atorvastatin Calcium } 20 \mathrm{mg} \text {, Omeprazole } 20 \\
\text { mg, Losartan Potassium } 50 \text { mg, Aricept } 10 \text { mg, } \\
\text { Paxil } 20 \text { mg, Namenda } 10 \mathrm{mg}\end{array}$ \\
\hline Male & 47 & Caucasian & Alzheimer's Disease (AD) & Donepezil $10 \mathrm{mg}$ \\
\hline Male & 67 & African & Alzheimer's Disease (AD) & Rivastigmine $3 \mathrm{mg}$, Multivitamin \\
\hline Male & 61 & Caucasian & $\begin{array}{l}\text { Alzheimer's Disease (AD), Type } 2 \text { Diabetes, } \\
\text { Hypertension (HTN), Hypercholesterolemia }\end{array}$ & $\begin{array}{l}\text { Atorvastatin } 40 \mathrm{mg} \text {, Gabapentin } 300 \mathrm{mg}, \\
\text { Aspirin } 81 \mathrm{mg} \text {, Razadyne } 16 \mathrm{mg} \text {, Metformin } \\
500 \mathrm{mg}\end{array}$ \\
\hline Female & 60 & African & Alzheimer's Disease (AD), Hypertension (HTN) & Clonidine $0.3 \mathrm{mg}$, Ambien, Quetiapine $300 \mathrm{mg}$ \\
\hline Male & 47 & N/A & Alzheimer's Disease (AD), Asthma, Anxiety & Gabapentin $300 \mathrm{mg}$ \\
\hline Male & 60 & African & Alzheimer's Disease (AD), Type 2 Diabetes & Donepezil, Metformin, Humalog \\
\hline Male & 74 & Caucasian & $\begin{array}{c}\text { Alzheimer's Disease (AD), Hypertension (HTN), } \\
\text { Hypercholesterolemia }\end{array}$ & $\begin{array}{c}\text { Aspirin } 80 \mathrm{mg} \text {, Plavix } 75 \mathrm{mg} \text {, Lisinopril } 25 \mathrm{mg} \text {, } \\
\text { Simvastatin } 10 \mathrm{mg} \text {, Digoxin } 30 \mathrm{mg} \text {, Metoprolol } \\
50 \mathrm{mg} \text {, Razadyne } 24 \mathrm{mg}\end{array}$ \\
\hline
\end{tabular}


Table 4. Cont.

\begin{tabular}{|c|c|c|c|c|}
\hline Gender & Age & Race & Diagnosis & Medications \\
\hline Male & 50 & African & Alzheimer's Disease (AD), Seizures & Keppra 500-750 mg, Exelon Patch \\
\hline Male & 67 & African & Alzheimer's Disease (AD), Hypertension (HTN) & $\begin{array}{c}\text { Aspirin } 81 \mathrm{mg} \text {, Lisinopril } 5 \mathrm{mg} \text {, Metoprolol } \\
\text { Succinate } 500 \mathrm{mg}\end{array}$ \\
\hline Male & 59 & Mixed Race & $\begin{array}{c}\text { Alzheimer's Disease (AD), Type } 2 \text { Diabetes, } \\
\text { Hypertension (HTN), Anxiety }\end{array}$ & $\begin{array}{c}\text { Metoprolol } 50 \text { mg, Amlodipine/Benazepril } \\
\text { 10-40 mg, Seroquel } 50 \mathrm{mg} \text {, Aricept } 23 \mathrm{mg} \text {, } \\
\text { Creon } 36000 \mathrm{IU}, \text { Gabapentin } 600 \mathrm{mg} \text {, Prandin } 2 \\
\text { mg, Metformin } 1000 \mathrm{mg}\end{array}$ \\
\hline Male & 54 & African & Alzheimer's Disease (AD), HTN & $\begin{array}{l}\text { Donepezil } 10 \mathrm{mg} \text {, Multivitamin, } \\
\text { Atenolol } 50 \mathrm{mg}\end{array}$ \\
\hline Female & 58 & $\mathrm{~N} / \mathrm{A}$ & $\begin{array}{c}\text { Alzheimer's Disease (AD), Asthma, Hypertension } \\
\text { (HTN), Hypercholesterolemia, Rheumatoid } \\
\text { Arthritis (RA), Type } 2 \text { Diabetes }\end{array}$ & $\begin{array}{c}\text { Combivent } 103 \mu \mathrm{g} \text {, Symbicort } 160 \mu \mathrm{g} \text {, } \\
\text { Budesonide } 0.5 \mathrm{mg} \text {, Singulair } 10 \mathrm{mg} \text {, Prandin } \\
2 \mathrm{mg} \text {, Metoprolol } 50 \mathrm{mg} \text {, Lotrel } 20 \mathrm{mg} \text {, Janumet } \\
1000 \mathrm{mg} \text {, Donepezil } 10 \mathrm{mg} \text {, Maxzide } 37.5 \mathrm{mg}\end{array}$ \\
\hline Male & 75 & Caucasian & $\begin{array}{c}\text { Osteomyelitis, Type } 2 \text { Diabetes, Chronic Kidney } \\
\text { Disease (CKD), Dyslipidemia, Hypertension } \\
\text { (HTN), Erectile Dysfunction (ED), Atherosclerosis, } \\
\text { Alzheimer's Disease (AD) }\end{array}$ & $\begin{array}{c}\text { Hydrochlorothiazide } 25 \mathrm{mg} \text {, Humalog } \\
100 \mathrm{U} / \mathrm{mL} \text {, Lantus } 100 \mathrm{U} / \mathrm{mL} \text {, Metformin } \\
\text { HCLHCL } 1000 \mathrm{mg} \text {, Testosterone Cypionate } 200 \\
\mathrm{mg} / \mathrm{mL} \text {, Amlodipine Besylate } 10 \mathrm{mg} \text {, Ventolin } \\
\text { HFA } 108 \mu \mathrm{g} \text {, Carvedilol } 25 \mathrm{mg} \text {, Lipitor } 20 \mathrm{mg} \text {, } \\
\text { Benazepril HCLHCL } 40 \mathrm{mg} \text {, Azithromycin } \\
250 \mathrm{mg} \text {, Proair } 108 \mu \mathrm{g}\end{array}$ \\
\hline Female & 75 & Caucasian & Alzheimer's Disease (AD), Allergy (Seasonal) & $\begin{array}{l}\text { Aricept } 10 \text { mg, Namenda } 10 \mathrm{mg} \text {, Calcitrate } \\
200 \mathrm{mg} \text {, Centrum Silver, Cetirizine } 10 \mathrm{mg} \text {, Folic } \\
\text { Acid } 400 \mu \mathrm{g} \text {, Magnesium } 250 \mathrm{mg}\end{array}$ \\
\hline Female & 73 & Caucasian & $\begin{array}{c}\text { Alzheimer's Disease (AD), Type } 2 \text { Diabetes, } \\
\text { Hypercholesterolemia, Coronary Artery Disease } \\
\text { (CAD) }\end{array}$ & $\begin{array}{l}\text { Vitamin D6, Folic Acid, Warfarin } 5 \mathrm{mg}, \\
\text { Losartan/Hydrochlorothiazide } 50 \mathrm{mg} / 12.5 \mathrm{mg} \text {, } \\
\text { Metformin } 500 \mathrm{mg} \text {, Aricept } 10 \mathrm{mg}\end{array}$ \\
\hline Male & 55 & N/A & $\begin{array}{c}\text { Alzheimer's Disease (AD), Hypertension (HTN), } \\
\text { Bilateral Carpal Tunnel }\end{array}$ & $\begin{array}{l}\text { Losartan/Hydrochlorothiazide } 50 \mathrm{mg} / 12.5 \mathrm{mg} \\
\text { Meloxicam } 15 \mathrm{mg} \text {, Norvasc } 10 \mathrm{mg}\end{array}$ \\
\hline Male & 84 & Caucasian & $\begin{array}{c}\text { Hypertension (HTN), Hypercholesterolemia, } \\
\text { Alzheimer's Disease (AD) }\end{array}$ & $\begin{array}{c}\text { Metoprolol } 25 \mathrm{mg} \text {, Atorvastatin } 40 \mathrm{mg} \text {, Aspirin } \\
81 \mathrm{mg} \text {, Theragran }\end{array}$ \\
\hline
\end{tabular}


Table 4. Cont.

\begin{tabular}{|c|c|c|c|c|}
\hline Gender & Age & Race & Diagnosis & Medications \\
\hline Male & 51 & African & $\begin{array}{c}\text { Alzheimer's Disease (AD), Hypertension (HTN), } \\
\text { Hypercholesterolemia }\end{array}$ & Hydrochlorothiazide $25 \mathrm{mg}$, Razadyne $16 \mathrm{mg}$ \\
\hline Male & 64 & N/A & $\begin{array}{l}\text { Alzheimer's Disease (AD), Hypertension (HTN), } \\
\text { Hypercholesterolemia, Type } 2 \text { Diabetes }\end{array}$ & $\begin{array}{c}\text { Exelon } 6 \text { mg, Metformin } 500 \text { mg, Atorvastatin } \\
40 \mu \mathrm{g} \text {, Ramipril } 10 \mathrm{mg} \text {, Lantus } 100 \mathrm{U} / \mathrm{mL}\end{array}$ \\
\hline Female & 84 & Caucasian & $\begin{array}{l}\text { Hypertension (HTN), Hallucinations, Psychoses, } \\
\text { Cellulitis, Dementia, Mitral Valve Prolapse (MVP), } \\
\text { Hyperlipidemia (HLD), Alzheimer's Disease (AD) }\end{array}$ & $\begin{array}{l}\text { Simvastatin } 20 \mathrm{mg} \text {, Potassium Chloride } \\
10 \mathrm{mEq} \text {, Amlodipine Besylate } 2.5 \mathrm{mg} \text {, } \\
\text { Dutasteride } 0.5 \mathrm{mg} \text {, Losartan Potassium } \\
100 \mathrm{mg} \text {, Aspirin } 81 \mathrm{mg} \text {, Furosemide } 20 \mathrm{mg}, \\
\text { Potassium Chloride } 10 \mathrm{mEq} \text {, Avodart } 0.4 \mathrm{mg} \text {, } \\
\text { Amlodipine Besylate } 2.5 \mathrm{mg} \text {, Ramipril } 10 \mathrm{mg}\end{array}$ \\
\hline Female & 62 & Caucasian & Sporadic Alzheimer's Disease (AD), Asthma & $\begin{array}{l}\text { Topamax } 150 \mathrm{mg} \text {, Vesicare } 5 \mathrm{mg} \text {, Prozac } 60 \mathrm{mg} \text {, } \\
\text { Levoxyl } 75 \mathrm{mg} \text {, Xarelto } 20 \mathrm{mg}, \\
\text { Hydrocodone-Acetaminophen } 5-325 \mathrm{mg}, \\
\text { Butran Patch } 15 \mathrm{mg} \text {, Gabapentin } 600 \mathrm{mg}, \\
\text { Celebrex } 200 \mathrm{mg} \text {, Breo } 100 \mathrm{mg} \text {, ProAir, Bentyl } \\
20 \mathrm{mg} \text {, Pantoprazole } 40 \mathrm{mg}\end{array}$ \\
\hline Male & 68 & Caucasian & $\begin{array}{c}\text { Alzheimer's Disease (AD), Type } 2 \text { Diabetes, } \\
\text { Hypertension (HTN), Hypercholesterolemia, } \\
\text { Cerebrovascular Accident (CVA), Parkinsonism, } \\
\text { Peripheral Neuropathy, Hypothyroidism, Benign } \\
\text { Prostatic Hyperplasia (BPH), Depression, Anxiety, } \\
\text { Glaucoma, Hernia }\end{array}$ & $\begin{array}{l}\text { NamEnda } 5 \text { mg, Tamsulosin HCLHCL } 0.4 \text { mg, } \\
\text { Atorvastatin } 40 \mathrm{mg} \text {, Valsartan } 320 \mathrm{mg} \text {, Zetia } \\
10 \mathrm{mg} \text {, Carvedilol } 25 \mathrm{mg} \text {, Aspirin } 325 \mathrm{mg}, \\
\text { Bupropion HCLl ER } 200 \mathrm{mg} \text {, Venlafaxine ER } \\
150 \mathrm{mg} \text {, Finasteride } 5 \mathrm{mg} \text {, Synthroid } 50 \mu \mathrm{g}, \\
\text { Zolpidem } 10 \mathrm{mg} \text {, Novolog } 100 \text { units } / \mathrm{mL} \text {, } \\
\text { Lantus } 100 \text { units } / \mathrm{mL} \text {, Latanoprost } 0.005 \% \text {, } \\
\text { Azelastine } 0.15 \% \text {, Glucagon } 1 \mathrm{mg}\end{array}$ \\
\hline Male & 72 & Caucasian & $\begin{array}{l}\text { Hypertension (HTN), Hypercholesterolemia, } \\
\text { Alzheimer's Disease (AD) }\end{array}$ & $\begin{array}{c}\text { Omega-3 Fatty acids/Docosahexanoic } \\
\text { acid/EPA/Fish oil } 350 \mathrm{mg} / 235 \mathrm{mg} / 90 \mathrm{mg} / 597 \\
\mathrm{mg}, \text { CoQ10 } 100 \mathrm{mg} \text {, Vitamin B Complex, } \\
\text { Aspirin } 81 \mathrm{mg}, \text { Pravastatin } 20 \mathrm{mg} \text {, Losartan } \\
50 \mathrm{mg} \text {, Namenda XR } 28 \mathrm{mg} \text {, Donepezil } 10 \mathrm{mg} \text {, } \\
\text { Crenizumab }\end{array}$ \\
\hline
\end{tabular}


Table 4. Cont.

\begin{tabular}{|c|c|c|c|c|}
\hline Gender & Age & Race & Diagnosis & Medications \\
\hline Male & 79 & Caucasian & $\begin{array}{c}\text { Asthma, Hypertension (HTN), } \\
\text { Hypercholesterolemia, Basal Cell Cancer (BCC), } \\
\text { Alzheimer's Disease (AD) }\end{array}$ & $\begin{array}{l}\text { Aspirin } 81 \mathrm{mg} \text {, Amlodipine/Benazepril } 10 \\
\text { mg/20 mg, Terazosin } 2 \mathrm{mg}, \\
\text { Hydrochlorothiazide } 25 \mathrm{mg} \text {, Atenolol } 50 \mathrm{mg} \text {, } \\
\text { Multivitamin, Calcium, Vitamin D, } \\
\text { Atorvastatin } 40 \mathrm{mg}\end{array}$ \\
\hline Female & 77 & Caucasian & $\begin{array}{l}\text { Hypertension (HTN), Allergic Rhinitis, Hematuria, } \\
\text { Chronic Kidney Disease (CKD), Hypertensive } \\
\text { Nephropathy, Hypercholesterolemia, Menopausal, } \\
\text { Osteopenia, Gastroesophageal Reflux Disease } \\
\text { (GERD), Large Hiatal Hernia, Gastritis, } \\
\text { Esophagitis, Basal Cell Cancer (BCC), } \\
\text { Degenerative Joint Disease, Rosacea, Alzheimer's } \\
\text { Disease (AD), Obesity, Dyspepsia }\end{array}$ & Vitamin D 2000 IU, Omeprazole 20 mg, Tylenol \\
\hline Male & 71 & Caucasian & $\begin{array}{l}\text { Atrial Fibrillation, End Stage Renal Disease } \\
\text { (ESRD), Congestive Heart Failure (CHF), Coronary } \\
\text { Artery Disease (CAD), Hyperlipidemia, Chronic } \\
\text { Obstructive Pulmonary Disease (COPD), } \\
\text { Gastroesophageal Reflux Disease (GERD), } \\
\text { Hyperparathyroidism, Alzheimer's Disease (AD) }\end{array}$ & $\begin{array}{c}\text { Lanthanum Carbonate } 1000 \mathrm{mg} \text {, Midodrine } 10 \\
\text { mg, Sensipar } 30 \mathrm{mg} \text {, Pantoprazole } 40 \mathrm{mg}, \\
\text { Pravastatin } 40 \mathrm{mg} \text {, Ventolin } 90 \mu \mathrm{g}, \\
\text { Warfarin } 3 \mathrm{mg}\end{array}$ \\
\hline Female & 82 & Caucasian & $\begin{array}{c}\text { Type } 2 \text { Diabetes, Hypothyroidism, Coronary } \\
\text { Artery Disease (CAD), Atrial Fibrillation (AF), } \\
\text { Hypertension (HTN), Alzheimer's Disease (AD), } \\
\text { Hyperlipidemia (HLD), Depression, Irritable } \\
\text { Bowel Syndrome (IBS), Cerebrovascular Accident } \\
\text { (CVA), Coronary Artery Disease (CAD), } \\
\text { Vertigo, Anemia }\end{array}$ & $\begin{array}{c}\text { Digoxin } 125 \mu \mathrm{g} \text {, Potassium Chloride } 20 \mathrm{mEq} \text {, } \\
\text { Metoprolol Succinate } 200 \mathrm{mg} \text {, Furosemide } 20 \\
\mathrm{mg} \text {, Levothyroxine Sodium } 88 \mu \mathrm{\mu g} \text {, Lipitor } 20 \\
\mathrm{mg} \text {, Memantine HCL } 5 \mathrm{mg} \text {, Lisinopril } 10 \mathrm{mg} \text {, } \\
\text { Xarelto } 15 \mathrm{mg} \text {, Amlodipine Besylate } 2.5 \mathrm{mg} \text {, } \\
\text { Zoloft } 50 \mathrm{mg} \text {, Aricept } 10 \mathrm{mg} \text {, Metformin HCL } \\
500 \mathrm{mg}\end{array}$ \\
\hline Male & 78 & Caucasian & $\begin{array}{l}\text { Chronic Kidney Disease (CKD), Diabetic } \\
\text { Nephropathy, Diabetic Neuropathy, Coronary } \\
\text { Artery Disease (CAD), History Of Myocardial } \\
\text { Infarction, Hyperlipidemia (HLD), Type } 1 \\
\text { Diabetes, Depression, Age Related Macular } \\
\text { Degeneration (AMD), Alzheimer's Disease (AD), } \\
\text { Dementia, Acute Renal Failure (ARF) }\end{array}$ & $\begin{array}{c}\text { Humalog Mix } 100 \mathrm{IU} \text {, Aspirin } 81 \mathrm{mg} \text {, Centrum } \\
\text { Silver, L-Glutamine, Metoprolol Succinate } 50 \\
\text { mg, Lipitor } 20 \mathrm{mg} \text {, Novolog, Humulin N, } \\
\text { Gabapentin } 100 \mathrm{mg} \text {, Alprazolam } 0.5 \mathrm{mg} \text {, } \\
\text { Fluticasone Propionate Cream, Citalopram } \\
\text { Hydrobromide } 20 \mathrm{mg} \text {, Cartia XT } 120 \mathrm{mg} \text {, } \\
\text { Aricept } 5 \mathrm{mg} \text {, Citalopram } \\
\text { Hydrobromide } 20 \mathrm{mg}\end{array}$ \\
\hline
\end{tabular}




\subsection{Biomarker Analyses}

Data obtained by the Simple Plex assay were analyzed with Prism 8 software (GraphPad Software, San Diego, CA, USA). First, outliers were removed, and receiver operating characteristics (ROC) were calculated, thus obtaining a $95 \%$ confidence interval, a standard deviation and a p-value. A cut-off point was then obtained for a range of different specificities and sensitivities and their respective likelihood ratio, as well as positive (PPV) and negative predictive values (NPV) and accuracy $[24,50]$.

\subsection{Statistical Analyses}

Normality was tested by the Shapiro-Wilk normality test, and statistical difference between groups was tested by a one-way ANOVA, followed by a Kruskal-Wallis test for multiple comparisons. $p$-value of significance was considered at less than 0.05. In addition, clustering was carried out using hierarchical clustering and Gaussian Mixture Modeling using RStudio software with the following libraries: cluster, caret, factorextra, magrittr, ggplot2 and mclust. Binomial logistic regressions for the outcome of having either MCI or AD were carried out using RStudio software with the following libraries: ggplot2, MASS, dplyr, broom and car.

Author Contributions: J.P.d.R.V., R.W.K., W.D.D., X.O.S., M.E.S. and M.C.D. conceived or designed the study. J.P.d.R.V., X.O.S., M.E.S. and M.C.D. were responsible for data collection. J.P.d.R.V. and X.O.S. contributed to data analyses and interpretation. All authors have read and agreed to the published version of the manuscript.

Funding: This research was funded by the 2019 Stanley J. Glaser Foundation Research Award to J.P.d.R.V. and an R01 grant from the NIH/NINDS to R.W.K. and J.P.d.R.V. (R01NS113969-01).

Conflicts of Interest: J.P.d.R.V., R.W.K. and W.D.D. are cofounders and managing members of InflamaCORE, LLC and have licensed patents on inflammasome proteins as biomarkers of injury and disease, as well as on targeting inflammasome proteins for therapeutic purposes. J.P.d.R.V., R.W.K. and W.D.D. are Scientific Advisory Board Members of ZyVersa Therapeutics. All other authors declare that there are no conflicts of interest. Data presented in this manuscript is protected under US Patent Application: 62/696,549 (Method for Detecting Inflammasome Proteins as Biomarkers of Neurological Disorders).

\section{References}

1. Padovani, A.; Borroni, B.; Colciaghi, F.; Pettenati, C.; Cottini, E.; Agosti, C.; Lenzi, G.L.; Caltagirone, C.; Trabucchi, M.; Cattabeni, F.; et al. Abnormalities in the pattern of platelet amyloid precursor protein forms in patients with mild cognitive impairment and Alzheimer disease. Arch. Neurol. 2002, 59, 71-75. [CrossRef]

2. Petersen, R.C. Aging, mild cognitive impairment, and Alzheimer's disease. Neurol. Clin. 2000, 18, 789-806. [CrossRef]

3. Petersen, R.C.; Smith, G.E.; Waring, S.C.; Ivnik, R.J.; Tangalos, E.G.; Kokmen, E. Mild cognitive impairment: Clinical characterization and outcome. Arch. Neurol. 1999, 56, 303-308. [CrossRef] [PubMed]

4. Bozoki, A.; Giordani, B.; Heidebrink, J.L.; Berent, S.; Foster, N.L. Mild cognitive impairments predict dementia in nondemented elderly patients with memory loss. Arch. Neurol. 2001, 58, 411-416. [CrossRef] [PubMed]

5. Morris, J.C.; Storandt, M.; Miller, J.P.; McKeel, D.W.; Price, J.L.; Rubin, E.H.; Berg, L. Mild cognitive impairment represents early-stage Alzheimer disease. Arch. Neurol. 2001, 58, 397-405. [CrossRef]

6. Blennow, K.; Hampel, H. CSF markers for incipient Alzheimer's disease. Lancet Neurol. 2003, 2, 605-613. [CrossRef]

7. Kanemaru, K.; Kameda, N.; Yamanouchi, H. Decreased CSF amyloid beta42 and normal tau levels in dementia with Lewy bodies. Neurology 2000, 54, 1875-1876. [CrossRef]

8. Sjogren, M.; Minthon, L.; Davidsson, P.; Granerus, A.K.; Clarberg, A.; Vanderstichele, H.; Vanmechelen, E.; Wallin, A.; Blennow, K. CSF levels of tau, beta-amyloid(1-42) and GAP-43 in frontotemporal dementia, other types of dementia and normal aging. J. Neural Transm. (Vienna) 2000, 107, 563-579.

9. Andreasen, N.; Sjogren, M.; Blennow, K. CSF markers for Alzheimer's disease: Total tau, phospho-tau and Abeta42. World J. Biol. Psychiatry 2003, 4, 147-155. [CrossRef]

10. Terajima, M.; Arai, H.; Itabashi, S.; Higuchi, M.; Zhu, C.; Kosaka, Y.; Nakagawa, T.; Sasaki, H. Elevated cerebrospinal fluid tau levels: Implications for the early diagnosis of Alzheimer's disease. J. Am. Geriatr. Soc. 1996, 44, 1012-1013. [CrossRef] 
11. Araki, W.; Hattori, K.; Kanemaru, K.; Yokoi, Y.; Omachi, Y.; Takano, H.; Sakata, M.; Yoshida, S.; Tsukamoto, T.; Murata, M.; et al. Re-evaluation of soluble APP-alpha and APP-beta in cerebrospinal fluid as potential biomarkers for early diagnosis of dementia disorders. Biomark Res. 2017, 5, 28. [CrossRef] [PubMed]

12. Zetterberg, H. Neurofilament Light: A Dynamic Cross-Disease Fluid Biomarker for Neurodegeneration. Neuron 2016, 91, 1-3. [CrossRef] [PubMed]

13. Parbo, P.; Madsen, L.S.; Ismail, R.; Zetterberg, H.; Blennow, K.; Eskildsen, S.F.; Vorup-Jensen, T.; Brooks, D.J. Low plasma neurofilament light levels associated with raised cortical microglial activation suggest inflammation acts to protect prodromal Alzheimer's disease. Alzheimers Res. Ther. 2020, 12, 3-7. [CrossRef] [PubMed]

14. Mayeli, M.; Mirshahvalad, S.M.; Aghamollaii, V.; Tafakhori, A.; Abdolalizadeh, A.; Rahmani, F. Plasma Neurofilament Light Chain Levels Are Associated With Cortical Hypometabolism in Alzheimer Disease Signature Regions. J. Neuropathol. Exp. Neurol. 2019, 78, 709-716. [CrossRef]

15. Pawelec, G.; Goldeck, D.; Derhovanessian, E. Inflammation, ageing and chronic disease. Curr. Opin. Immunol. 2014, 29, 23-28. [CrossRef] [PubMed]

16. Aden, K.; Rosenstiel, P. The Dark Age(ing) of the Inflammasome. Immunity 2017, 46, 173-175. [CrossRef]

17. Latz, E.; Duewell, P. NLRP3 inflammasome activation in inflammaging. Semin. Immunol. 2018, 40, 61-73. [CrossRef]

18. Mawhinney, L.J.; de Rivero Vaccari, J.P.; Dale, G.A.; Keane, R.W.; Bramlett, H.M. Heightened inflammasome activation is linked to age-related cognitive impairment in Fischer 344 rats. BMC Neurosci. 2011, 12, 123. [CrossRef]

19. Mejias, N.H.; Martinez, C.C.; Stephens, M.E.; de Rivero Vaccari, J.P. Contribution of the inflammasome to inflammaging. J. Inflamm. (Lond) 2018, 15, 23. [CrossRef]

20. Platnich, J.M.; Muruve, D.A. NOD-like receptors and inflammasomes: A review of their canonical and non-canonical signaling pathways. Arch. Biochem. Biophys. 2019, 670, 4-14. [CrossRef]

21. Franklin, B.S.; Bossaller, L.; De Nardo, D.; Ratter, J.M.; Stutz, A.; Engels, G.; Brenker, C.; Nordhoff, M.; Mirandola, S.R.; Al-Amoudi, A.; et al. The adaptor ASC has extracellular and 'prionoid' activities that propagate inflammation. Nat. Immunol. 2014, 15, 727-737. [CrossRef]

22. Kerr, N.; Lee, S.W.; Perez-Barcena, J.; Crespi, C.; Ibanez, J.; Bullock, M.R.; Dietrich, W.D.; Keane, R.W.; de Rivero Vaccari, J.P. Inflammasome proteins as biomarkers of traumatic brain injury. PLoS ONE 2018, 13, e0210128. [CrossRef]

23. Kerr, N.; Garcia-Contreras, M.; Abbassi, S.; Mejias, N.H.; Desousa, B.R.; Ricordi, C.; Dietrich, W.D.; Keane, R.W.; de Rivero Vaccari, J.P. Inflammasome Proteins in Serum and Serum-Derived Extracellular Vesicles as Biomarkers of Stroke. Front. Mol. Neurosci. 2018, 11, 309. [CrossRef] [PubMed]

24. Keane, R.W.; Dietrich, W.D.; de Rivero Vaccari, J.P. Inflammasome Proteins As Biomarkers of Multiple Sclerosis. Front. Neurol. 2018, 9, 135. [CrossRef] [PubMed]

25. Syed, S.A.; Beurel, E.; Loewenstein, D.A.; Lowell, J.A.; Craighead, W.E.; Dunlop, B.W.; Mayberg, H.S.; Dhabhar, F.; Dietrich, W.D.; Keane, R.W.; et al. Defective Inflammatory Pathways in Never-Treated Depressed Patients Are Associated with Poor Treatment Response. Neuron 2018, 99, 914-924.e3. [CrossRef] [PubMed]

26. Friker, L.L.; Scheiblich, H.; Hochheiser, I.V.; Brinkschulte, R.; Riedel, D.; Latz, E.; Geyer, M.; Heneka, M.T. beta-Amyloid Clustering around ASC Fibrils Boosts Its Toxicity in Microglia. Cell Rep. 2020, 30, 3743-3754.e6. [CrossRef] [PubMed]

27. Venegas, C.; Kumar, S.; Franklin, B.S.; Dierkes, T.; Brinkschulte, R.; Tejera, D.; Vieira-Saecker, A.; Schwartz, S.; Santarelli, F.; Kummer, M.P.; et al. Microglia-derived ASC specks cross-seed amyloid-beta in Alzheimer's disease. Nature 2017, 552, 355-361. [CrossRef] [PubMed]

28. De Rivero Vaccari, J.P.; Brand, F.J., III; Sedaghat, C.; Mash, D.C.; Dietrich, W.D.; Keane, R.W. RIG-1 receptor expression in the pathology of Alzheimer's disease. J. Neuroinflamm 2014, 11, 67. [CrossRef]

29. Brubaker, A.L.; Palmer, J.L.; Kovacs, E.J. Age-related Dysregulation of Inflammation and Innate Immunity: Lessons Learned from Rodent Models. Aging Dis. 2011, 2, 346-360.

30. Liu, D.; Cao, B.; Zhao, Y.; Huang, H.; McIntyre, R.S.; Rosenblat, J.D.; Zhou, H. Soluble TREM2 changes during the clinical course of Alzheimer's disease: A meta-analysis. Neurosci. Lett. 2018, 686, 10-16. [CrossRef]

31. Lynch, M.A. Age-related neuroinflammatory changes negatively impact on neuronal function. Front. Aging Neurosci. 2010, 1, 6. [CrossRef] 
32. Calabrese, V.; Giordano, J.; Signorile, A.; Laura Ontario, M.; Castorina, S.; De Pasquale, C.; Eckert, G.; Calabrese, E.J. Major pathogenic mechanisms in vascular dementia: Roles of cellular stress response and hormesis in neuroprotection. J. Neurosci. Res. 2016, 94, 1588-1603. [CrossRef] [PubMed]

33. Singhal, G.; Jaehne, E.J.; Corrigan, F.; Toben, C.; Baune, B.T. Inflammasomes in neuroinflammation and changes in brain function: A focused review. Front. Neurosci. 2014, 8, 315. [CrossRef]

34. Weinstein, G.; Lutski, M.; Goldbourt, U.; Tanne, D. C-reactive protein is related to future cognitive impairment and decline in elderly individuals with cardiovascular disease. Arch. Gerontol. Geriatr. 2017, 69, 31-37. [CrossRef]

35. Sloane, J.A.; Hollander, W.; Moss, M.B.; Rosene, D.L.; Abraham, C.R. Increased microglial activation and protein nitration in white matter of the aging monkey. Neurobiol. Aging 1999, 20, 395-405. [CrossRef]

36. Prolla, T.A. DNA microarray analysis of the aging brain. Chem. Senses 2002, 27, 299-306. [CrossRef]

37. Adamczak, S.; Dale, G.; de Rivero Vaccari, J.P.; Bullock, M.R.; Dietrich, W.D.; Keane, R.W. Inflammasome proteins in cerebrospinal fluid of brain-injured patients as biomarkers of functional outcome: Clinical article. J. Neurosurg. 2012, 117, 1119-1125. [CrossRef]

38. Yap, J.K.Y.; Pickard, B.S.; Chan, E.W.L.; Gan, S.Y. The Role of Neuronal NLRP1 Inflammasome in Alzheimer's Disease: Bringing Neurons into the Neuroinflammation Game. Mol. Neurobiol. 2019, 56, 7741-7753. [CrossRef]

39. Yin, J.; Zhao, F.; Chojnacki, J.E.; Fulp, J.; Klein, W.L.; Zhang, S.; Zhu, X. NLRP3 Inflammasome Inhibitor Ameliorates Amyloid Pathology in a Mouse Model of Alzheimer's Disease. Mol. Neurobiol. 2018, 55, 1977-1987. [CrossRef]

40. Saco, T.; Parthasarathy, P.T.; Cho, Y.; Lockey, R.F.; Kolliputi, N. Inflammasome: A new trigger of Alzheimer's disease. Front. Aging Neurosci. 2014, 6, 80. [CrossRef]

41. Tan, M.S.; Yu, J.T.; Jiang, T.; Zhu, X.C.; Tan, L. The NLRP3 inflammasome in Alzheimer's disease. Mol. Neurobiol. 2013, 48, 875-882. [CrossRef] [PubMed]

42. De Rivero Vaccari, J.P.; Dietrich, W.D.; Keane, R.W. Therapeutics targeting the inflammasome after central nervous system injury. Transl. Res. 2016, 167, 35-45. [CrossRef]

43. De Rivero Vaccari, J.P.; Lotocki, G.; Alonso, O.F.; Bramlett, H.M.; Dietrich, W.D.; Keane, R.W. Therapeutic neutralization of the NLRP1 inflammasome reduces the innate immune response and improves histopathology after traumatic brain injury. J. Cereb. Blood Flow Metab. 2009, 29, 1251-1261. [CrossRef] [PubMed]

44. De Rivero Vaccari, J.P.; Lotocki, G.; Marcillo, A.E.; Dietrich, W.D.; Keane, R.W. A molecular platform in neurons regulates inflammation after spinal cord injury. J. Neurosci. 2008, 28, 3404-3414. [CrossRef] [PubMed]

45. Desu, H.L.; Plastini, M.; Illiano, P.; Bramlett, H.M.; Dietrich, W.D.; de Rivero Vaccari, J.P.; Brambilla, R.; Keane, R.W. IC100: A novel anti-ASC monoclonal antibody improves functional outcomes in an animal model of multiple sclerosis. J. Neuroinflamm. 2020, 17, 143. [CrossRef]

46. Kerr, N.A.; de Rivero Vaccari, J.P.; Abbassi, S.; Kaur, H.; Zambrano, R.; Wu, S.; Dietrich, W.D.; Keane, R.W. Traumatic Brain Injury-Induced Acute Lung Injury: Evidence for Activation and Inhibition of a Neural-Respiratory-Inflammasome Axis. J. Neurotrauma 2018, 35, 2067-2076. [CrossRef]

47. Lee, S.W.; de Rivero Vaccari, J.P.; Truettner, J.S.; Dietrich, W.D.; Keane, R.W. The role of microglial inflammasome activation in pyroptotic cell death following penetrating traumatic brain injury. J. Neuroinflamm. 2019, 16, 27. [CrossRef]

48. Knopman, D.S.; Penman, A.D.; Catellier, D.J.; Coker, L.H.; Shibata, D.K.; Sharrett, A.R.; Mosley, T.H., Jr. Vascular risk factors and longitudinal changes on brain MRI: The ARIC study. Neurology 2011, 76, 1879-1885. [CrossRef]

49. Cerhan, J.R.; Folsom, A.R.; Mortimer, J.A.; Shahar, E.; Knopman, D.S.; McGovern, P.G.; Hays, M.A.; Crum, L.D.; Heiss, G. Correlates of cognitive function in middle-aged adults. Atherosclerosis Risk in Communities (ARIC) Study Investigators. Gerontology 1998, 44, 95-105. [CrossRef]

50. Brand, F.J., 3rd; Forouzandeh, M.; Kaur, H.; Travascio, F.; de Rivero Vaccari, J.P. Acidification changes affect the inflammasome in human nucleus pulposus cells. J. Inflamm. (Lond) 2016, 13, 29. [CrossRef]

(C) 2020 by the authors. Licensee MDPI, Basel, Switzerland. This article is an open access article distributed under the terms and conditions of the Creative Commons Attribution (CC BY) license (http://creativecommons.org/licenses/by/4.0/). 